\title{
Physiochemical Restrictions of Mineral Zoning of Sediment-Hosted Stratiform Copper Deposit in SW China
}

\author{
Yan Zhang $\mathbb{D},{ }^{1}$ Runsheng Han $\mathbb{D},{ }^{1}$ Shuming Wen, ${ }^{2}$ and Pingtang Wei ${ }^{3}$ \\ ${ }^{1}$ Southwest Institute of Geological Survey, Geological Survey Center for Non-Ferrous Mineral Resources, \\ Kunming University of Science and Technology, Kunming 650093, China \\ ${ }^{2}$ State Key Laboratory of Complex Nonferrous Metal Resources Clean Utilization, Kunming University of Science and Technology, \\ Kunming 650093, China \\ ${ }^{3}$ Kunming Geological Prospecting Institute, China Metallurgical Geological Bureau, Kunming, Yunnan 650024, China \\ Correspondence should be addressed to Runsheng Han; 554670042@qq.com
}

Received 4 November 2017; Accepted 22 January 2018; Published 26 February 2018

Academic Editor: Andri Stefansson

Copyright (C) 2018 Yan Zhang et al. This is an open access article distributed under the Creative Commons Attribution License, which permits unrestricted use, distribution, and reproduction in any medium, provided the original work is properly cited.

\begin{abstract}
The Chuxiong basin, located in southwest China, is well known as a mineralization area of red-bed type copper deposits in China. These deposits are characterized by mineral zoning, which is especially true for the Dayao deposits. The mineral zoning is consistent for both horizontal and vertical zoning; from the base (center) of the ore body to the top (outermost), the mineral zones are from hematite, chalcocite, chalcocite + bornite, and bornite + chalcopyrite to pyrite. We studied the mineral zoning in detail using a thermodynamic phase diagram method, such as $\log f_{\mathrm{O}_{2}}-\log f_{\mathrm{S}_{2}}, \mathrm{pH}-\log f_{\mathrm{O}_{2}}$, and $\mathrm{pH}-\mathrm{Eh}$, and discussed the constraints on the order of the minerals precipitation under different physiochemical conditions. It is indicated that changes in temperature have little effect on $\mathrm{pH}$ and $\mathrm{Eh}$ in the formation of minerals. $\mathrm{S}^{2-}$ is stable only below $473 \mathrm{~K}$, and the forming temperature of chalcocite must be below $473 \mathrm{~K}$. In this paper, we also explain the mineral zoning formation mechanism and propose that the main controlling factor of mineral zoning is $\mathrm{pH}$. Because this mineral zoning is widespread in sediment-hosted deposits, studies on this mechanism can considerably promote better understanding of the genesis of ore deposits in order to guide the exploration.
\end{abstract}

\section{Introduction}

Sediment-hosted stratiform copper deposit (SSC), concerned by many researchers [1-11], occurs in many places around the world $[7,12-15]$. It is frequently labeled as "stratiform" or "stratabound" and/or "diagenetic," which ranks the second largest source of copper after porphyry copper-type, approximately accounting for about $20-25 \%$ of the global copper reserves [6]. SSC deposits are mainly distributed in the central Africa copper belt; central Europe copper belt; Kodaro-Udokan copper belt, Russia; Dzhekagan copper belt Kazakhstan; Dongchuang copper district, China; BeltPurcell copper belt, USA; Redstone copper belt, Canada; and Chuxiong basin-hosted copper deposits, China [11], as represented by the Zambia and Zaire copper deposits in central Africa [16], Udokan and Jezkazgan copper deposits in the former Soviet Union [17], Kupferschiefer copper deposits in Zechstein basin [18], and so on.
As early as 1960s, Carpenter [19] and White [20] began to study the zoning phenomena in the White Pine sedimentary copper deposits, Michigan, USA. Brown [21] proposed the metallogenic model of SSC deposits and believed that copper deposits of this kind occurred in the contact between red and grey clastic horizons of redox interface and had a typical sulfide zoning: chalcocite, bornite, chalcopyrite, and pyrite. In fact, mineral zonation both laterally and vertically from pyrite to chalcopyrite to bornite to chalcocite to hematite is characteristic of SSC copper deposits [11,22]. This pattern from pyrite to copper-rich minerals (chalcocite) has been described for many deposits [1, 6, 22-29]. The same mineral zoning is found in red-bed deposits widely, one of the basic broad categories in SSC deposits [1, 6, 22, 30-32].

The red-bed type copper deposits in China are mainly distributed in southern Cretaceous red-bed basins, one of the most famous is Chuxiong basin, followed by Huili basin of Sichuan Province, Yuanma basin, and Hengyang basin 
of Hunan Province. Chuxiong basin-hosted copper deposits were formed in the layers near the redox interface marked by the transition from purple to light grey sandstones and have an obvious mineral assemblage zoning from purple to light color layers: hematite, chalcocite, bornite, chalcopyrite, and pyrite $[27,33]$. It is by no accident that deposits of this kind are characteristics of such notable mineral zoning and they originate depending on their geochemical properties and their precipitation processes.

In addition, many researchers have extensively studied the red-bed type copper deposits in China and made great achievements [23, 34-46]. Tu [47] put forward the geochemical model for sedimentary and reforming metallogenesis. Ran et al. $[48,49]$ systematically investigated the geochemistry of copper, salt, and organic matter associated deposits in Chuxiong Basin and the floor structure of copper deposits, especially in experimental studies on organic geochemistry. Zhuang et al. [50] discussed the metallogenic process of copper deposits through water-rock interaction. Wang [51] made the regional metallogenic prediction of copper deposits in Chuxiong basin. Tan [52] studied the red-bed type copper deposits from the geochemistry and metallogenic dynamics points of view. $\mathrm{Li}$ and $\mathrm{Pu}$ [43] extensively studied the redbed type copper deposits in Lanping-Simao basin, western Yunnan Province, especially on their transformation, and further discussed the mechanisms underlying mineral activation, migration, and precipitation in the surrounding rocks using experimental geochemical method.

In these researches on the mineral zoning characteristics of red-bed type copper deposits in Chuxiong basin, they pointed out that metallic minerals zoning is controlled by the oxidation-reduction conditions during the principal metallogenic epoch $[53,54]$. Chen et al. [55] studied the zoning characteristics and the genesis of red-bed type deposits of the Chuxiong basin and suggested that mineral zoning resulted from the interactions of the oxidizing brine rich in cooper with the reducing sulfurous fluid, while minerals precipitation at the different stages resulted from these interactions. Gao [56] made a $\mathrm{pH}$-Eh phase diagram at $T=323.8 \mathrm{~K}$, based on which they affirmed that minerals zoning is controlled by $\mathrm{pH}$ under reducing condition.

However, the physiochemical conditions for the formation of mineral assemblages in Chuxiong Basin-hosted copper deposits have not been well studied. By choosing a representative deposit, the Dayao copper deposit and using the thermodynamic phase diagram method, in this paper, we explored the restrictions on the process of hydrothermal migration and precipitation of sulfides at different $\mathrm{pH}$, Eh, oxygen fugacity, and sulfur fugacity and explained the reasons for mineral assemblage zoning in the Dayao redbed copper deposit. Moreover, based on the thermodynamic theory, we also investigated the precipitation mechanism of $\mathrm{Cu}-\mathrm{Fe}$ sulfides to reveal the main controlling factors of oreforming element zoning in the Chuxiong basin.

\section{Geological Setting}

The Chuxiong basin is located in the middle of Yunnan Province, China, and verges to the southwest of Yangtze block and the west side of Yuanmou ancient land. It belongs to the jointing area of the western Tethys tectonic domain as well as the southeast Indian and Eurasian plate collision and is surrounded by the Kangdian earth's axis in the east, the south China Caledonian-Variscan fold belt in the south, the Sanjiang Tethys tectonic belt in the northwest, and the Songpan-Ganzi block in the north [41, 57]. Wang [51] divided the basin into three primary tectonic units near N-S trending, namely, the western thrust belt, central depression belt, and eastern uplift belt, and subdivided them into 11 secondary tectonic units, as shown in Figure 1(a). The basin experienced three evolution stages: namely, the downfaulted, depression, and shrinking periods, where each had a different sedimentary formation. From the Late Cretaceous, the basin stepped into its contraction stage and started to deposit red clastic rocks, which provides an important condition for copper deposits [58].

A total of 313 red-bed copper deposits (points) have been found on the mouding slope in Chuxiong basin. As seen in Figure 1(b), they form a NW arc copper belt and distribute along the margin of Yuanmou ancient continent. The copper deposits span crosses a long time period of concentrated mineralization and could be divided into 16 segments from Late Triassic to Tertiary, almost covering each layer of Cenozoic and Mesozoic. But the main copper deposits are distributed in the Aodiju segment of Gaofensi formation (8.60\%) in lower Cretaceous, Liuju segment $(61.00 \%)$, and Dacun segment (24.12\%) of Matushan formation in upper Cretaceous, in total, accounting for $93.37 \%$ of copper reserves in the basin.

Copper deposits and prospects are widely distributed from the north to the south in Tuanshan, Dacun, Wadiju, Liuju, Hao jiahe, Tongchangqing, Geyizha, Jiziwan, and Laoqingshan within the basin. Among them, the Dayao deposit hosted by Matoushan formation $\left(\mathrm{K}_{2} \mathrm{~m}\right)$ of upper Cretaceous has reserves of about $44 \mathrm{Mt}$ of grades $1.2 \% \mathrm{Cu}$ and is considered as the typical and giant copper deposit (Figure 2). The major metallic minerals of the Dayao deposit are often characterized by a zoning pattern of hematite, chalcocite, chalcocite + bornite, bornite + chalcopyrite, and pyrite. The forming mechanism of this regular pattern is a key scientific issue in studying the genesis of such type of deposits.

\section{Mineral Zoning of the Red-Bed Type Copper Deposits in Chuxiong Basin}

The formation of the red-bed type Dayao copper deposit includes three processes: sedimentation-diagenesis, primary reformation, and secondary reformation, among which the first two processes played important roles in the formation of the deposits.

Chen et al. [23] studied the zoning characteristics and the genesis of the red-bed copper deposits of the Chuxiong basin and concluded that there are two presenting forms (Figure 3) because of their different genesis. One is zoning along the layer (horizontal zoning) from purple sandstone to light grey sandstone within the rock, which forms the mineral assemblage zoning of hematite, chalcocite, bornite, chalcopyrite, and pyrite. This zoning generally does not cut 

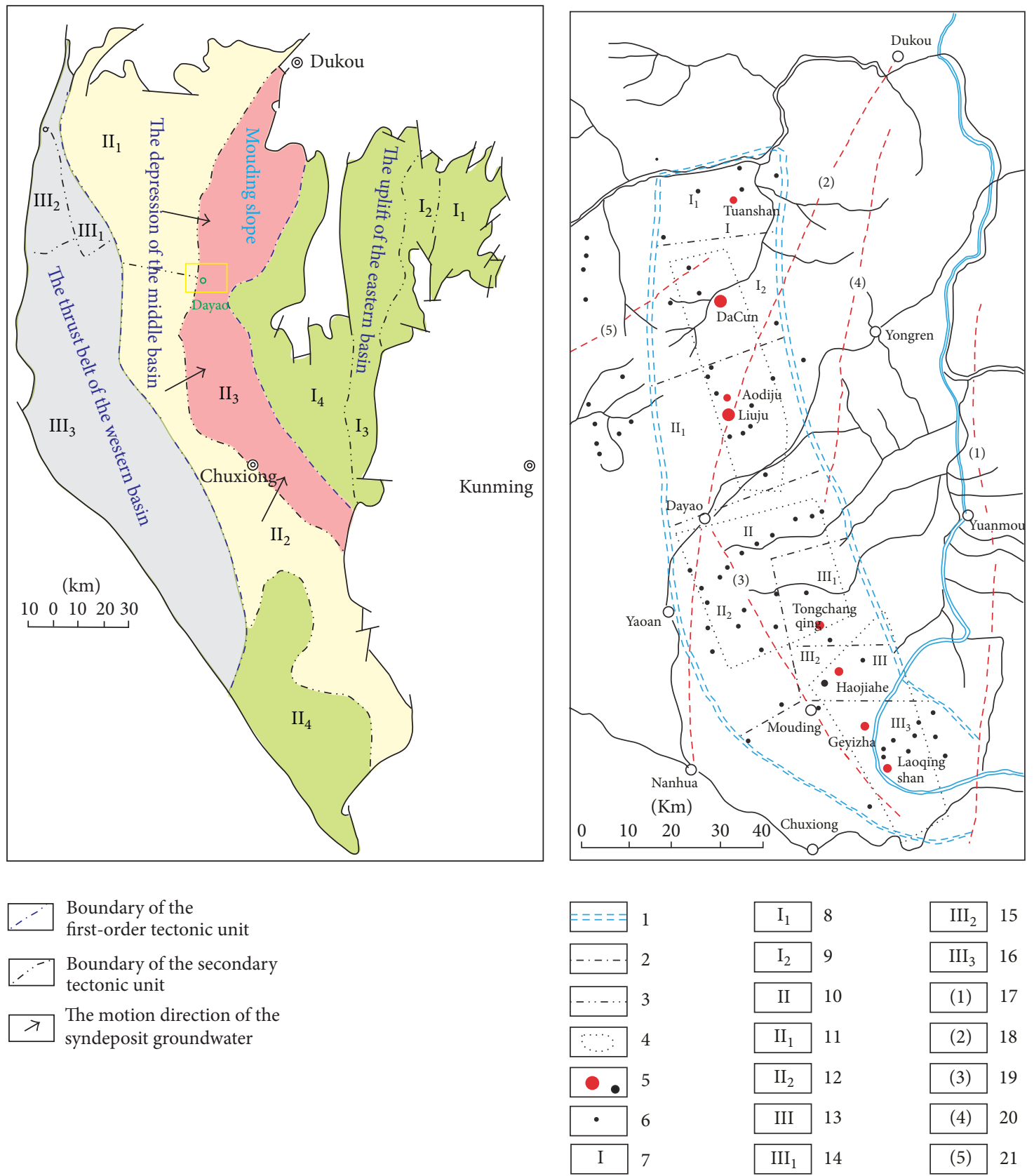

(a)

(b)

FIGURE 1: The tectonic unit (a) and arcuate red-bed copper belt (b) in Chuxiong basin (modified from [51]). (a) I: the uplift of the eastern basin; I1: Yunlong depression; $\mathrm{I}_{2}$ : Yinachang salient; $\mathrm{I}_{3}$ : Dongshan depression; $\mathrm{I}_{4}$ : Yuanmou salient; II: the depression of the middle basin; $\mathrm{II}_{1}$ : Yanfeng depression; $\mathrm{II}_{2}$ : Shuangbai depression; $\mathrm{II}_{3}$ : mouding slope; $\mathrm{II}_{4}$ : Dahongshan salient; III: the thrust belt of the western basin; III $\mathrm{I}_{1}$ : Pingchuan salient; $\mathrm{III}_{2}$ : Pianjiao depression; $\mathrm{III}_{3}$ : the thrust belt of the western basin. (b) 1: the red-bed copper belt; 2 : mineralization concentration area; 3: mineralization area; 4: anomaly of $\mathrm{Cu}-\mathrm{Pb}-\mathrm{Zn}$; 5: medium-small scale copper deposit; 6: copper spot; 7: Tuanshan-Dacun mineralization concentration area; 8: Tuanshan-Wulong area; 9: Dacun area; 10: Liuju-Longjie mineralization concentration area; 11: Liuju area; 12: Longjie area; 13: Sanmu-Tongchangqing-Shibanhe mineralization concentration area; 14: Sanmu-Tongchangqing area; 15: Haojiahe area; 16: GeyizhaShibanhe area; 17: Lvzhijiang fault; 18: Dukou-Nanhua fault; 19: Qian Chang-Mouding fault; 20: Lixidong fault; and 21: Binchuan-Wulong fault.

through layers or only cut through layers in a small angle and is common in sandstone type ore deposits. The other is zoning along the vertical direction (vertical zoning) generally from the base to top, which forms the mineral assemblage zoning of hematite, chalcocite, bornite, chalcopyrite, and pyrite. This zoning usually cuts through the formation interface in a large angle and is common in shale type ore deposits.

Based on the detailed field geological work, we found that because of the weak reformation the zoning in Dayao copper deposits is mainly horizontal zoning. Metal sulfide zoning 

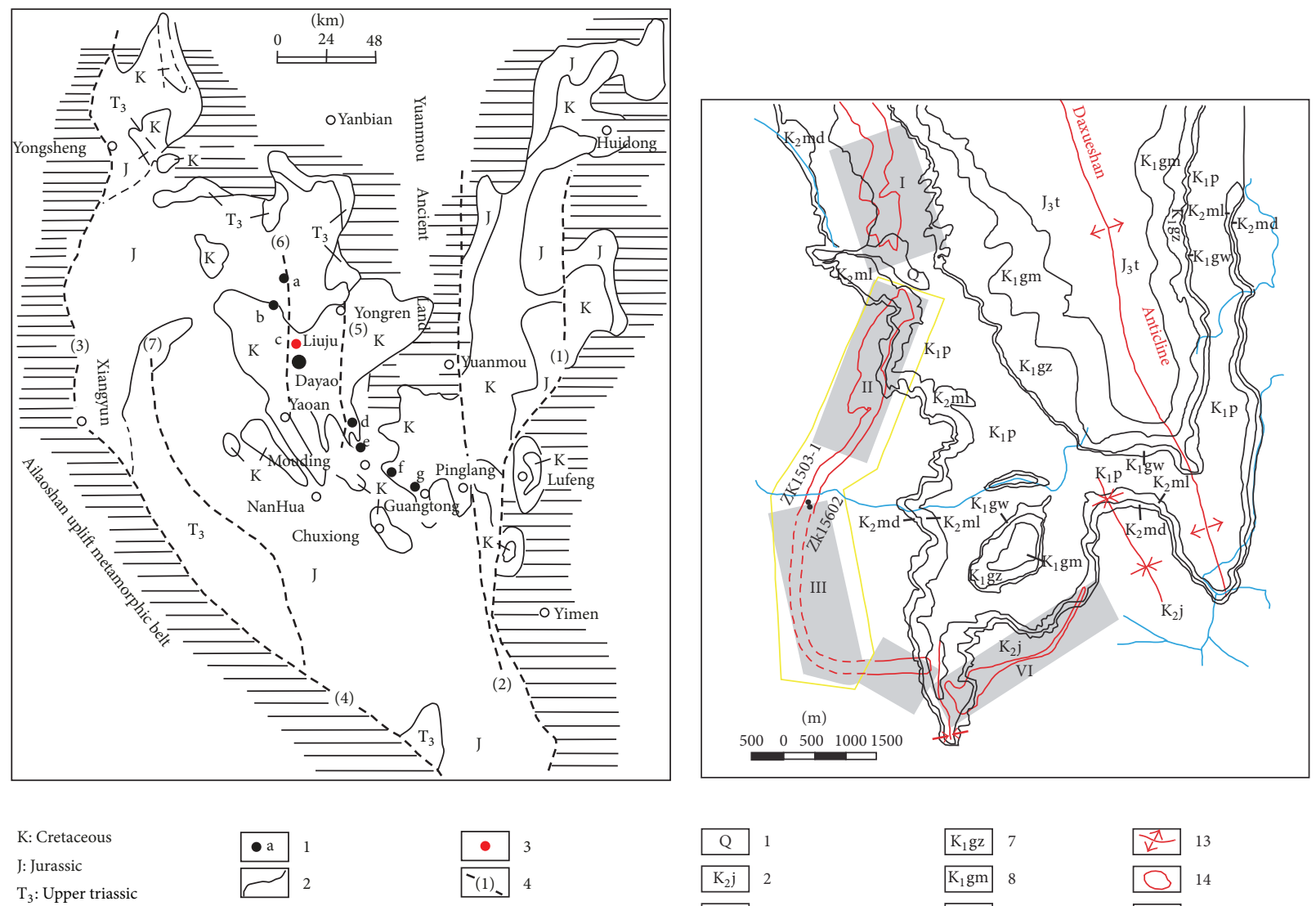

\begin{tabular}{|c|c|}
\hline $\mathrm{Q}$ & \\
\hline $\mathrm{K}_{2} \mathrm{j}$ & \\
\hline $\mathrm{K}_{2} \mathrm{md}$ & \\
\hline $\mathrm{K}_{2} \mathrm{ml}$ & \\
\hline $\mathrm{K}_{1} \mathrm{P}$ & \\
\hline & \\
\hline
\end{tabular}

(a)

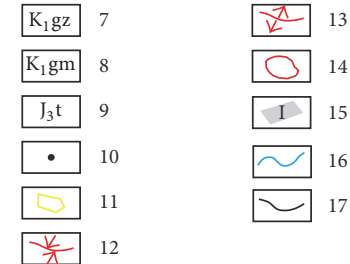

(b)

FIGURE 2: (a) Geological sketch of the Chuxiong basin; (b) Geology of the Dayao copper deposit (modified from measured geological map). (a) 1: copper deposits: a, Tuanshan deposit; b, Dacun deposit; c, Liuju deposit; d, Tongchangqing deposit; e, Haojiahe deposit; f, Geyizha deposit; and g, Laoqingshan deposit; 2: geological boundaries; 3: research area; and 4: fracture: (1) Puduhe fracture; (2) Lvzhijiang fracture; (3) Chenghai fracture; (4) Honghe fracture; (5) Lixidong fracture; (6) Huaping-Dayao fracture; and (7) Yupaojiang fracture. (b) 1: Quaternery; 2: Jiangdihe Formation $\left(\mathrm{K}_{2} \mathrm{j}\right)$; 3: Dacuan segment $\left(\mathrm{K}_{2} \mathrm{md}\right)$ of Matoushan Formation; 4: Liuju subsegment $\left(\mathrm{K}_{2} \mathrm{ml}_{1}\right)$ of Matoushan Formation; 5: Puchanghe Formation $\left(\mathrm{K}_{1} \mathrm{p}\right)$; 6: Aodiju segment $\left(\mathrm{K}_{1} \mathrm{gw}\right)$ of Gaofengsi Formation; 7: Zhename segment $\left(\mathrm{K}_{1} \mathrm{gz}\right)$ of Gaofengsi Formation; 8: Meiyipo segment of Gaofengs Formation $\left(\mathrm{K}_{1} \mathrm{gm}\right)$; 9: Tuodian Formation $\left(\mathrm{J}_{3} \mathrm{t}\right)$; 10: Sampling location; 11: Research area; 12: Syncline; 13: Anticline; 14: ore body; and 15: ore district: I, Aodiju deposit; II, Liuju ore district; III, Xiaohe-Shimenkan ore district; and IV, LuojimuzuoYanzikou ore district; 16: Water system; and 17: stratigraphic boundary.

ranges from grain (Figures 4 and 5) to deposit scale (Figure 6), reflecting directions of fluid flow and/or chemical gradients. It was formed during the sedimentation-diagenesis period, from purple sandstone to light grey sandstone: forming the mineral zoning of hematite + (minor) native copper, chalcocite + bornite, bornite + chalcopyrite, chalcopyrite + pyrite, and pyrite (Figures 4-6). The primary minerals are simple, mainly chalcocite and bornite or chalcopyrite and pyrite $[23,27]$.

Mineralized replacement features may follow zones with the highest prelithification permeability. The relationships of mutualistic symbiosis between chalcocite and bornite, chalcopyrite and bornite, and pyrite and chalcopyrite are common with metasomatic texture (Figure 6). The metasomatic sequence is shown as hematite, chalcocite, bornite, chalcopyrite, and pyrite. The former was replaced by the latter, so the regular level zoning pattern of the mineral assemblages is from the purple sandstone to light grey sandstone, that is, hematite zone (the purple rock zone and the margin of the ore body), hematite + chalcocite zone, chalcocite + bornite zone, bornite + chalcocite + pyrite zone, chalcopyrite + bornite zone, chalcopyrite + pyrite zone, and pyrite zone (the margin of light grey sandstone) [27]. A relatively obvious mineral zoning is also formed during the structure reformation period, but the scale of such kind of ore body is usually small and narrow. 


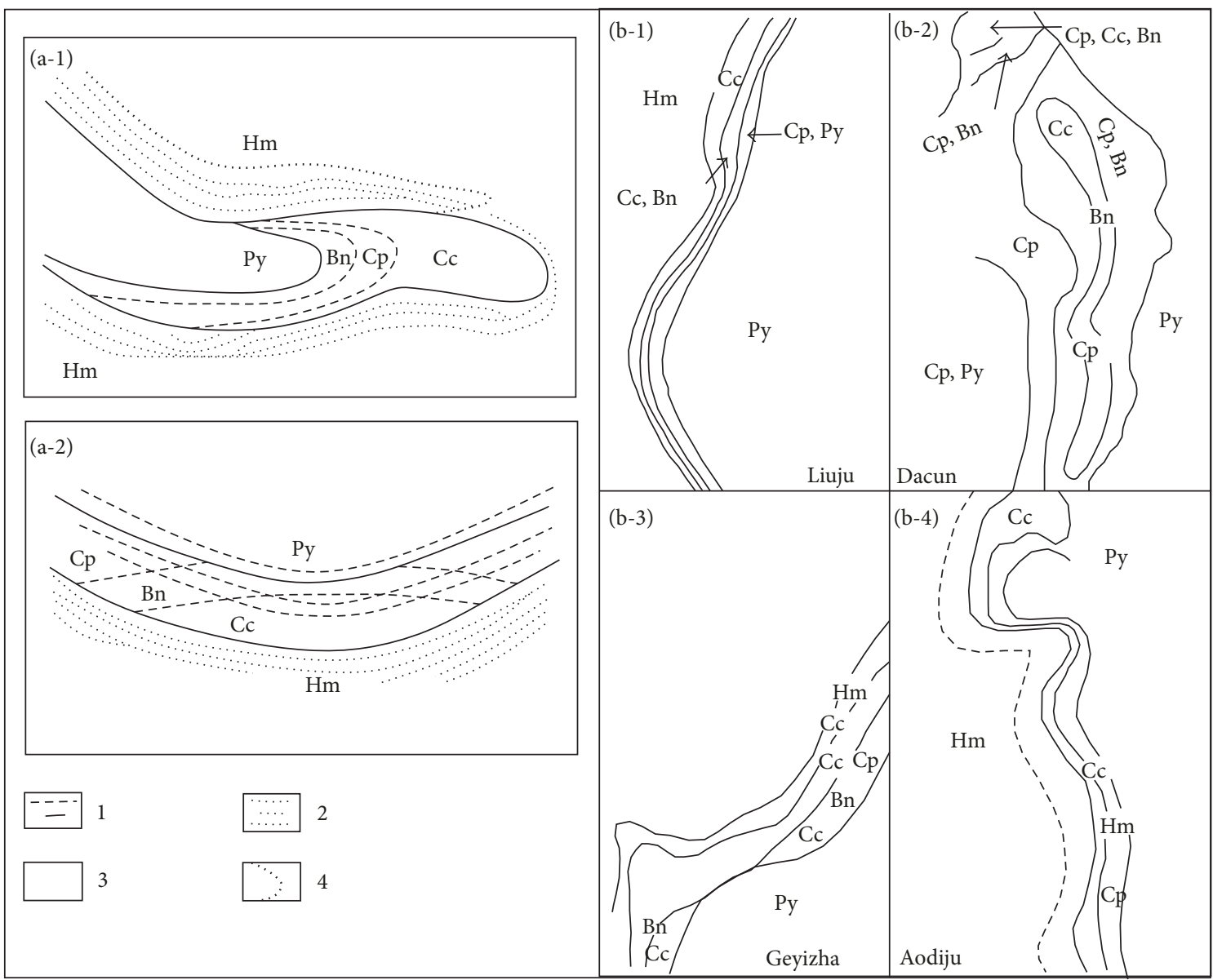

FIGURE 3: (a) Two-idea zoning pattern of metal minerals in red-bed copper deposits in the Chuxiong basin; (b) pattern of metal mineral zoning in the section (modified by [23]). (a-1) Horizontal zoning; (a-2) vertical zoning; 1: light grey sandstone; 2: purple sandstone; 3: orebodies; and 4: the boundary of mineral zoning; (b-1) Liuzu deposit; (b-2) Dacun deposit; (b-3) Geyizha deposit; and (b-4) Aodiju deposit. Py: pyrite; Cp: chalcopyrite; $\mathrm{Bn}$ : bornite; Cc: chalcocite; Hm: hematite.

\section{Methods}

Currently, studies on geological phase diagram, especially on the thermodynamics software, are mainly restricted to oxidation of the ores, such as THERMOCALC software [59] and PELE software [60]. There is no corresponding thermodynamics software to date for the low pressure and low temperature sulfide system.

To describe the paragenetic assemblage relationship of minerals, a chemical equation of the ore minerals is built. The thermodynamic data reported by Lin et al. [61] range within the interval of $100 \mathrm{~K}$; thus, Lagrange's interpolation can be used to calculate the Gibbs free energy of formation $\Delta G$ of the compound which is within the interval of $50 \mathrm{~K}$ at temperature from $373 \mathrm{~K}$ to $523 \mathrm{~K}$.

4.1. Fluid Inclusion Temperature of the Dayao Copper Deposit. According to the studies by Ran and Liu [48] and Wu [62] on fluid inclusion temperature of the Dayao copper deposit (Table 1), the formation temperature of the deposits ranges from $373 \mathrm{~K}$ to $523 \mathrm{~K}$, of which the ore-forming temperature in the sedimentation-diagenesis metallogenic period is $373 \mathrm{~K}-423 \mathrm{~K}$, and the temperature in the reformation metallogenic period is $373 \mathrm{~K}-523 \mathrm{~K}$, mostly below $473 \mathrm{~K}$. Therefore, the Dayao copper deposit is generally formed at low temperature.

4.2. $\mathrm{pH}$-Eh Phase Diagram. In the hydrothermal solution, the stable condition and equilibrium relationship of the mineral are controlled by $\mathrm{pH}$ and $\mathrm{Eh}$ of the solution and the activity of ions in the solution. Thus, the Nernst equation can be used to calculate the Eh of the reaction equation [63]

$$
\begin{aligned}
\mathrm{Eh} & =\mathrm{Eh}_{0}+\left(\frac{R T}{n F}\right) \ln \left(\frac{[\text { oxidation state }]}{\text { [reduction state }]}\right), \\
\mathrm{Eh}_{0} & =\frac{\Delta G_{R, T} \theta}{n F}
\end{aligned}
$$

where $F$ is the Faraday constant with value of $96500 \mathrm{C} / \mathrm{mol}$, $R$ is the perfect gas constant with value of $8.314 \mathrm{~J} /(\mathrm{K} \cdot \mathrm{mol}), n$ is the number of electrons gained or lost in the oxidationreduction reaction, and [oxidation state] and [reduction state] are the concentration of each kind of ions at oxidation and reduction states, respectively. 


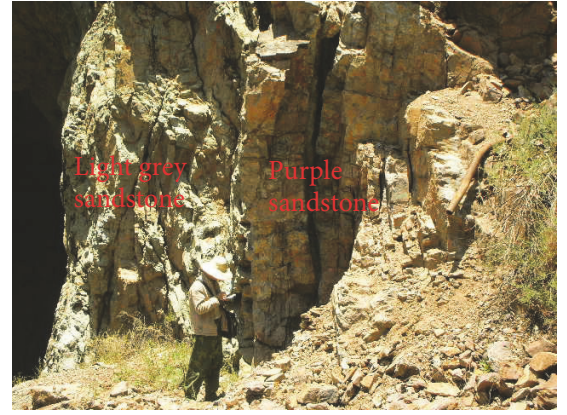

(a)

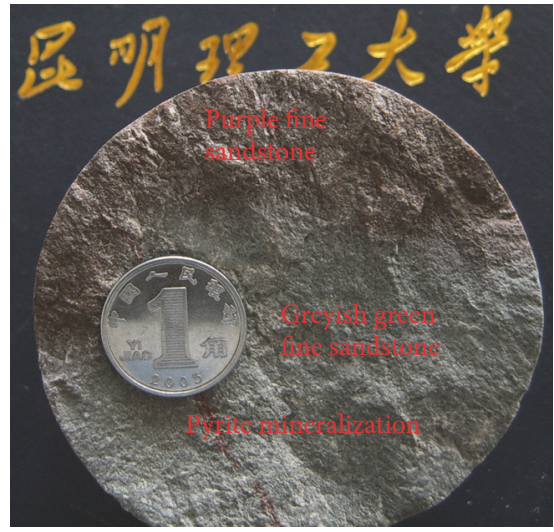

(c)

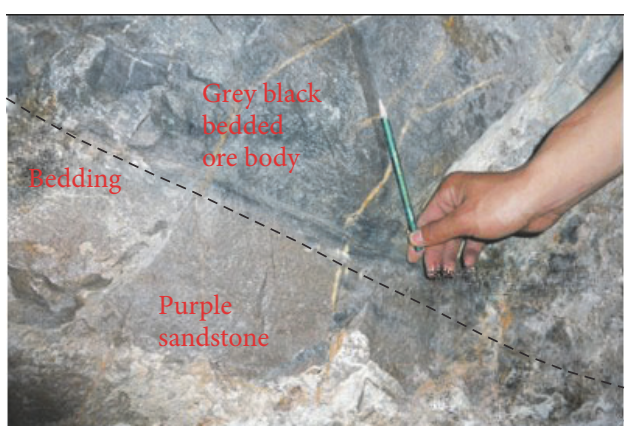

(b)

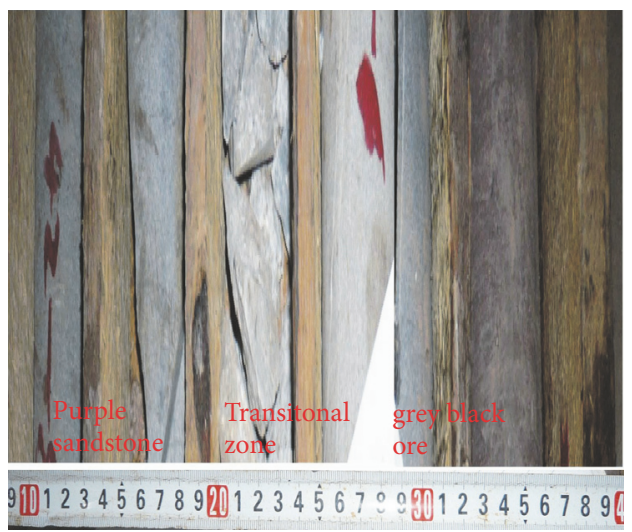

(d)

FIGURE 4: The macroscopic geological characteristics with the change of purple to light grey in Dayao copper deposit. (a) 074DB-29 point: the boundary line between the purple sandstone and the light grey sandstone in bottom of $\mathrm{K}_{2} \mathrm{ml}_{1}$ in Shimenkan. Silicified and alteration happened in light grey sandstone side and it made the purple sandstone fade; (b) MK16: the boundary line of purple under the bedding and light grey above the bedding because of the hydrothermal metasomatism along the bedding, the color on the plate, and fracture into light grey to grey; (c) 96 m of ZK1503-1 drill: the transition between the purple fine sandstone and the greyish green fine sandstone in $\mathrm{K}_{2} \mathrm{ml}_{2}$, pyrite mineralization in greyish green fine sandstone; (d) ZK15103: the transition of purple and light grey and the mineralization characteristics (left: purple sandstone; middle: transition of purple and light grey; and right: grey black ore).

TABLE 1: Homogeneous temperature of fluid inclusions of minerals in the Dayao deposit.

\begin{tabular}{|c|c|c|c|c|c|c|}
\hline \multirow{2}{*}{ Mineral } & \multirow{2}{*}{ Metallogenesis } & \multirow{2}{*}{ Sample numbers } & \multirow{2}{*}{ Gas-liquid ratio (\%) } & \multicolumn{2}{|c|}{ Homogeneous temperature $\left({ }^{\circ} \mathrm{C}\right)$} & \multirow{2}{*}{ Source of date } \\
\hline & & & & Range & Average & \\
\hline Calcite & Diagenesis & 13 & $5 \sim 15$ & $116 \sim 145$ & 133 & \\
\hline \multirow{2}{*}{ Quartz } & \multirow{2}{*}{ Reformation } & 2 & $5 \sim 15$ & $158 \sim 205$ & 182 & (1) \\
\hline & & 2 & $25 \sim 45$ & $302 \sim 332$ & 317 & \\
\hline \multirow{3}{*}{ Quartz } & Diagenesis & 14 & $2 \sim 30$ & $96 \sim 137$ & $120,260 \sim 300$ & \\
\hline & Main reformation & 15 & $2 \sim 25$ & $123 \sim 209$ & 149 & (2) \\
\hline & Minor reformation & 6 & $2 \sim 25$ & $97 \sim 129$ & 113 & \\
\hline
\end{tabular}

Note. Source of data: (1) Ran and Zhuang [49], tested by the center analysis room of Zhongnan University; (2) Wu [62], tested by Nanjing University.

In order to construct and draw $\mathrm{pH}-\mathrm{Eh}$ phase diagram in the $\mathrm{Cu}-\mathrm{O}-\mathrm{S}-\mathrm{Fe}$ hydrothermal system [64-66], the chemical equations in the solution were established first (Table 2). Then, the thermodynamic data $[61,67,68]$ were put into Formula (1) to establish the expression of $\mathrm{pH}$-Eh and eventually to draw the phase diagram (Figure 7). The balanced lines drawn by reactions (25), (26), and (29) are ignored because they have exceeded the stability range of water. Because the ionization constant of water changes with temperature, the abscissa (i.e., $\mathrm{pH}$ ) needs to be set accordingly based on the ionization constants of water at $373 \mathrm{~K}, 423 \mathrm{~K}, 473 \mathrm{~K}$, and $523 \mathrm{~K}$, which are $12.264,11.642,11.302$, and 11.012, respectively.

4.3. $\mathrm{PH}-\log f_{\mathrm{O}_{2}}$ Phase Diagram. The $\mathrm{pH}-\log f_{\mathrm{O} 2}$ equation diagram of each chemical reaction is listed in Table 2. Take reaction (1) as an example; its equation is $\mathrm{Eh}=1.167-$ 


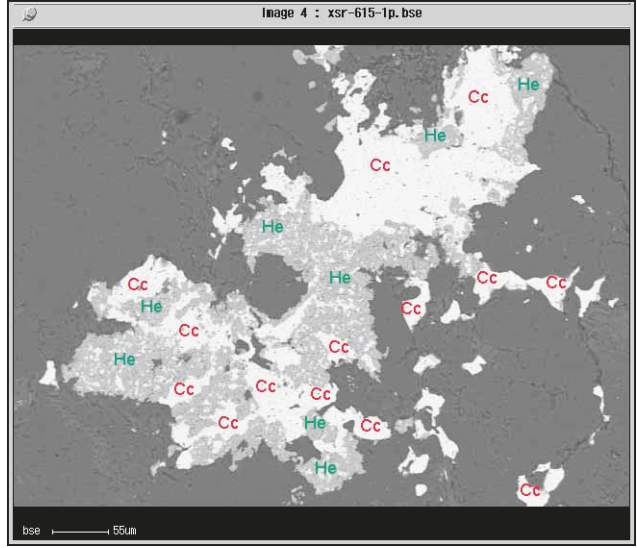

(a)

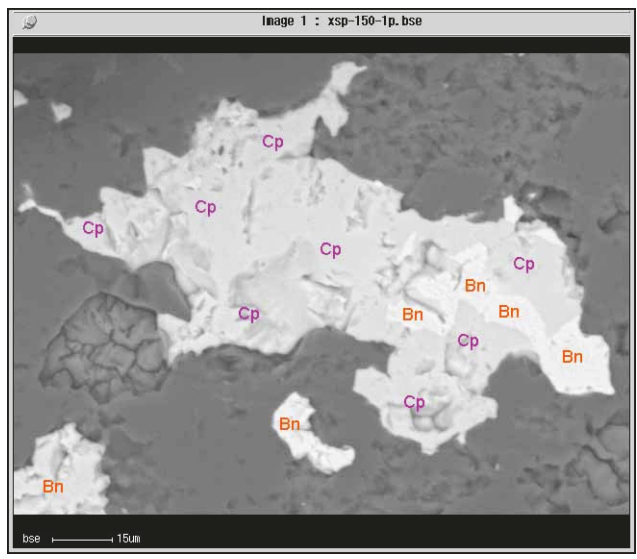

(c)

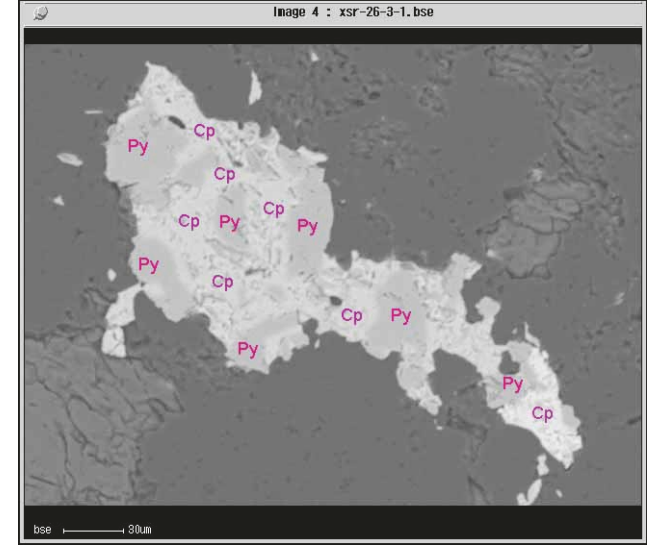

(b)

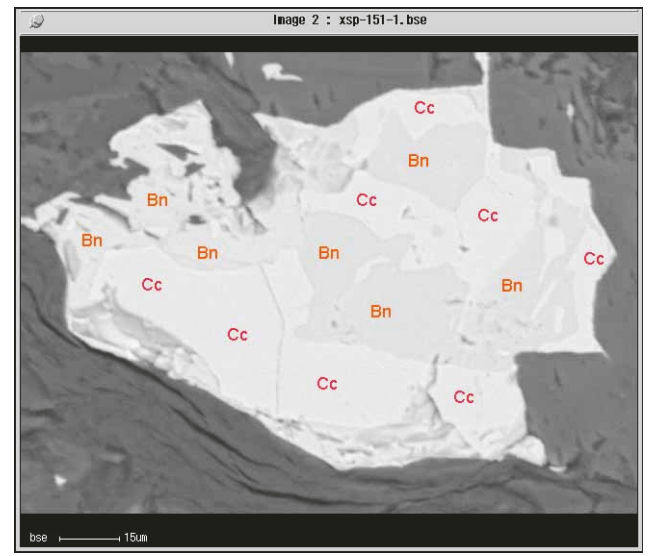

(d)

FIGURE 5: The texture and mineral composition of ore in the Dayao copper deposit. (a) Chalcocite (Cc) replacement by hematite (He) (XSR6151); (b) pyrite (Py) replacement by chalcopyrite (Cp) (XSR-26-3-1); (c) chalcopyrite (Cp) replacement by bornite (Bn) (XSR-150-1); and (d) bornite (Bn) replacement by chalcocite (Cc) (XSR-151-1). The sample location is ZK15602 (XSR-615-1) and ZK1503-1 (XSR-26-3-1, XSR-150-1, and XSR-151-1) (see Figures 2(b) and 4).

$0.074 \mathrm{pH}+0.0185 \log f_{\mathrm{O} 2}$. Then Eh of each reaction can be calculated by inputting the values of $\mathrm{pH}$ and $\log f_{\mathrm{O}_{2}}$ into the equation (Table 3 ) and used to draw the phase diagram (Figure 8).

4.4. $\log f_{\mathrm{O}_{2}}-\log f_{\mathrm{S}_{2}}$ Phase Diagram. The oxygen fugacity and sulfur fugacity are calculated using the formula below:

$$
\Delta G_{R, T}{ }^{\theta}=-2.303 R T \log \prod_{i}^{m} f_{i}^{C i}
$$

where $\Delta G$ or delta is under standard conditions.

For the reactions in which oxygen and sulfur participated simultaneously, the Gibbs-Duhem Equations (i.e., stoichiometric coefficient) of oxygen and sulfur are used to for calculation at certain points and subsequently to draw the balanced line of each reaction and calculate its slope. Table 4 lists $\log f_{\mathrm{O}_{2}}, \log f_{\mathrm{S}_{2}}$, and slope of each reaction and Figure 9 shows the $\log f_{\mathrm{O}_{2}}-\log f_{\mathrm{S}_{2}}$ phase diagram of each reaction.

\section{Results}

5.1. Constraints of $p H$, Eh, and $\log f_{\mathrm{O}_{2}}$ on Sulfide Precipitation. The range of $\mathrm{pH}$, Eh, and $\log f_{\mathrm{O}_{2}}$ of metal sulfides and the following cognition can be obtained from Figures 7 and 8 .

(1) $\mathrm{S}^{2-}$ can only exist stably in the hydrothermal solution at temperature below $473 \mathrm{~K}$. When the temperature of hydrothermal solution is higher than $473 \mathrm{~K}$, the chalcocite $\left(\mathrm{Cu}_{2} \mathrm{~S}\right)$ is not precipitated.

(2) The formation of mineral assemblage zoning was controlled by multiple factors including $\mathrm{Eh}$ and $\mathrm{pH}$. From $\mathrm{FeS}_{2}, \mathrm{CuFeS}_{2}$, and $\mathrm{Cu}_{5} \mathrm{FeS}_{4}$ to $\mathrm{Cu}_{2} \mathrm{~S}, \mathrm{pH}$ increases and $\mathrm{Eh}$ decreases; in other words, the environment turns from acidic to alkaline and from relatively oxidation state into strong reduction state.

(3) Variation of temperature has different impacts on Eh or $\mathrm{pH}$ for different sulfide. For $\mathrm{FeS}_{2}$ and $\mathrm{Cu}_{2} \mathrm{~S}$, temperature change has no significant impacts on $\mathrm{Eh}$ and $\mathrm{pH}$ of mineral precipitation. For $\mathrm{CuFeS}_{2}$ and $\mathrm{Cu}_{5} \mathrm{FeS}_{4}$, although temperature change has no significant effects on Eh, alkalinity 
TABLE 2: Chemical reactions and Eh-pH expressions.

Chemical reactions

$\mathrm{pH}$-Eh expressions

(1) $2 \mathrm{H}_{2} \mathrm{O}=\mathrm{O}_{2}+4 \mathrm{H}^{+}+4 \mathrm{e}$

(2) $\mathrm{H}_{2}=2 \mathrm{H}^{+}+2 \mathrm{e}$

(3) $\mathrm{HSO}_{4}{ }^{-}=\mathrm{SO}_{4}{ }^{2-}+\mathrm{H}^{+}$

(4) $\mathrm{S}+4 \mathrm{H}_{2} \mathrm{O}=\mathrm{HSO}_{4}{ }^{-}+7 \mathrm{H}^{+}+6 \mathrm{e}$

(5) $\mathrm{S}+4 \mathrm{H}_{2} \mathrm{O}=\mathrm{SO}_{4}{ }^{2-}+8 \mathrm{H}^{+}+6 \mathrm{e}$

(6) $\mathrm{H}_{2} \mathrm{~S}=\mathrm{S}+2 \mathrm{H}^{+}+2 \mathrm{e}$

(7) $\mathrm{H}_{2} \mathrm{~S}=\mathrm{HS}^{-}+\mathrm{H}^{+}$

(8) $\mathrm{HS}^{-}+4 \mathrm{H}_{2} \mathrm{O}=\mathrm{SO}_{4}{ }^{2-}+9 \mathrm{H}^{+}+8 \mathrm{e}$

(9) $\mathrm{HS}^{-}=\mathrm{S}^{2-}+\mathrm{H}^{+}$

(10) $\mathrm{S}^{2-}+4 \mathrm{H}_{2} \mathrm{O}=\mathrm{SO}_{4}{ }^{2-}+8 \mathrm{H}^{+}+8 \mathrm{e}$

(11) $3 \mathrm{Fe}+4 \mathrm{H}_{2} \mathrm{O}=\mathrm{Fe}_{3} \mathrm{O}_{4}+8 \mathrm{H}^{+}+8 \mathrm{e}$

(12) $2 \mathrm{Fe}_{3} \mathrm{O}_{4}+\mathrm{H}_{2} \mathrm{O}=3 \mathrm{Fe}_{2} \mathrm{O}_{3}+2 \mathrm{H}^{+}+2 \mathrm{e}$

(13) $\mathrm{Fe}^{2+}=\mathrm{Fe}^{3+}+\mathrm{e}$

(14) $2 \mathrm{Fe}^{2+}+3 \mathrm{H}_{2} \mathrm{O}=\mathrm{Fe}_{2} \mathrm{O}_{3}+6 \mathrm{H}^{+}+2 \mathrm{e}$

(15) $3 \mathrm{Fe}^{2+}+4 \mathrm{H}_{2} \mathrm{O}=\mathrm{Fe}_{3} \mathrm{O}_{4}+8 \mathrm{H}^{+}+2 \mathrm{e}$

(16) $2 \mathrm{Fe}^{3+}+3 \mathrm{H}_{2} \mathrm{O}=\mathrm{Fe}_{2} \mathrm{O}_{3}+6 \mathrm{H}^{+}$

(17) $2 \mathrm{Cu}+4 \mathrm{H}_{2} \mathrm{O}=\mathrm{Cu}_{2} \mathrm{O}+2 \mathrm{H}^{+}+2 \mathrm{e}$

(18) $\mathrm{Cu}_{2} \mathrm{O}+\mathrm{H}_{2} \mathrm{O}=2 \mathrm{CuO}+2 \mathrm{H}^{+}+2 \mathrm{e}$

(19) $\mathrm{Cu}^{+}=\mathrm{Cu}^{2+}+\mathrm{e}$

(20) $\mathrm{Cu}^{+}+\mathrm{e}=\mathrm{Cu}$

(21) $2 \mathrm{Cu}^{+}+\mathrm{H}_{2} \mathrm{O}=\mathrm{Cu}_{2} \mathrm{O}+2 \mathrm{H}^{+}$

(22) $\mathrm{Cu}^{2+}+\mathrm{H}_{2} \mathrm{O}=\mathrm{CuO}+2 \mathrm{H}^{+}$

(23) $2 \mathrm{Cu}^{2+}+\mathrm{H}_{2} \mathrm{O}=\mathrm{Cu}_{2} \mathrm{O}+2 \mathrm{H}^{+}+2 \mathrm{e}$

(24) $\mathrm{Fe}^{2+}+2 \mathrm{H}_{2} \mathrm{~S}=\mathrm{FeS}_{2}+4 \mathrm{H}^{+}+2 \mathrm{e}$

(25) $\mathrm{Fe}^{2+}+\mathrm{S}_{2}+2 \mathrm{e}=\mathrm{FeS}_{2}$

(26) $\mathrm{Cu}^{+}+\mathrm{SO}_{4}{ }^{2-}=\mathrm{Cu}^{2+}+\mathrm{SO}_{3}{ }^{2-}+\mathrm{e}$

(27) $2 \mathrm{FeS}_{2}+\mathrm{Cu}^{2+}+4 \mathrm{H}^{+}+4 \mathrm{e}=\mathrm{CuFeS}_{2}+\mathrm{Fe}^{2+}+2 \mathrm{H}_{2} \mathrm{~S}$

(28) $2 \mathrm{CuFeS}_{2}+3 \mathrm{Cu}^{2+}=\mathrm{Cu}_{5} \mathrm{FeS}_{4}+\mathrm{Fe}^{2+}+4 \mathrm{e}$

(29) $2 \mathrm{Cu}^{+}+\mathrm{S}^{2-}=\mathrm{Cu}_{2} \mathrm{~S}$

(30) $15 \mathrm{Cu}_{2} \mathrm{~S}+2 \mathrm{Fe}_{3} \mathrm{O}_{4}+7 \mathrm{H}^{+}+9 \mathrm{HS}^{-}=6 \mathrm{Cu}_{5} \mathrm{FeS}_{4}+$

$8 \mathrm{H}_{2} \mathrm{O}+2 \mathrm{e}$

$473 \mathrm{~K} \quad 423 \mathrm{~K}$

$1.129-0.104 \mathrm{pH}$

$-0.104 \mathrm{pH}$

$\mathrm{pH}=5.40$

$0.367-0.121 \mathrm{pH}$

$0.462-0.138 \mathrm{pH}$

$0.233-0.104 \mathrm{pH}$

$\mathrm{pH}=7.61$

$0.305-0.117 \mathrm{pH}$

$\mathrm{pH}=11.43$

$0.157-0.104 \mathrm{pH}$

$-0.085-0.104 \mathrm{pH}$

$0.24-0.104 \mathrm{pH}$

0.95

$1.602-0.341 \mathrm{pH}$

$2.258-0.456 \mathrm{pH}$

$\mathrm{pH}=1.18$

$0.46-0.104 \mathrm{pH}$

$0.67-0.104 \mathrm{pH}$

0.37

$-0.30$

$\mathrm{pH}=9.53$

$\mathrm{pH}=6.23$

$0.622-0.104 \mathrm{pH}$

$-0.63$

$-0.16+0.104 \mathrm{pH}$

$-0.59$

$-4.86+0.364 \mathrm{pH}$

$1.142-0.094 \mathrm{pH}$

$-0.094 \mathrm{pH}$

$\mathrm{pH}=4.56$

$0.340-0.110 \mathrm{pH}$

$0.411-0.125 \mathrm{pH}$

$0.220-0.094 \mathrm{pH}$

$\mathrm{pH}=7.09$

$0.280-0.106 \mathrm{pH}$

$\mathrm{pH}=11.28$

$0.148-0.094 \mathrm{pH}$

$-0.903-0.094 \mathrm{pH}$

$0.22-0.094 \mathrm{pH}$

0.94

$1.352-0.282 \mathrm{pH}$

$1.918-0.376 \mathrm{pH}$

$\mathrm{pH}=1.11$

$0.45-0.094 \mathrm{pH}$

$0.65-0.094 \mathrm{pH}$

$$
0.32
$$

$-0.36$

$$
\mathrm{pH}=9.05
$$

$$
\mathrm{pH}=6.32
$$

$0.532-0.094 \mathrm{pH}$

$-0.67$

$-0.15+0.094 \mathrm{pH}$

$-0.59$
$-4.34+0.329 \mathrm{pH} \quad-3.96+0.294 \mathrm{pH}$
$-0.72$

$-0.77$

$-0.14+0.084 \mathrm{pH}$

$-0.59$

$-0.14+0.074 \mathrm{pH}$

$-0.6$

$1.167-0.074 \mathrm{pH}$

$-0.074 \mathrm{pH}$

$\mathrm{pH}=2.98$

$0.288-0.086 \mathrm{pH}$

$0.325-0.099 \mathrm{pH}$

$0.205-0.074 \mathrm{pH}$

$\mathrm{pH}=6.57$

$0.235-0.083 \mathrm{pH}$

$\mathrm{pH}=11.68$

$0.127-0.074 \mathrm{pH}$

$-0.112-0.074 \mathrm{pH}$

$0.17-0.074 \mathrm{pH}$

0.86

$1.142-0.222 \mathrm{pH}$

$1.628-0.296 \mathrm{pH}$

$$
\mathrm{pH}=1.3
$$

$0.44-0.074 \mathrm{pH}$

$0.62-0.074 \mathrm{pH}$

0.22

$-0.45$

$\mathrm{pH}=7.86$

$\mathrm{pH}=6.60$

$0.362-0.074 \mathrm{pH}$

$0.462-0.084 \mathrm{pH}$

$-2.1+0.259 \mathrm{pH}$

TABLE 3: pH- $\log f_{\mathrm{O}_{2}}$ expressions.

\begin{tabular}{lcccc}
\hline No. & $T=523 \mathrm{~K}$ & $T=473 \mathrm{~K}$ & $T$ & $T=423 \mathrm{~K}$ \\
\hline$(1)$ & -25.7 & -48.6 & -55.5 & -63.1 \\
$(2)$ & -25.7 & -48.6 & -55.5 & -63.1 \\
$(3)$ & $\mathrm{pH}=5.40$ & $\mathrm{pH}=4.56$ & $\mathrm{pH}=3.73$ & $\mathrm{pH}=2.98$ \\
$(4)$ & $-29.3-0.65 \mathrm{pH}$ & $-34.1-0.68 \mathrm{pH}$ & $-39.8-0.67 \mathrm{pH}$ & $-47.5-0.65 \mathrm{pH}$ \\
$(5)$ & $-25.6-1.31 \mathrm{pH}$ & $-31.1-1.32 \mathrm{pH}$ & $-37.2-1.33 \mathrm{pH}$ & $-45.5-1.35 \mathrm{pH}$ \\
$(6)$ & -34.4 & -39.2 & -45.5 & -52 \\
$(7)$ & $\mathrm{pH}=7.61$ & $\mathrm{pH}=7.09$ & $\mathrm{pH}=6.71$ & $-42.8-0.48 \mathrm{pH}$ \\
$(8)$ & $-31.7-0.50 \mathrm{pH}$ & $-36.7-0.51 \mathrm{pH}$ & -6.57 \\
$(9)$ & $\mathrm{pH}=11.43$ & $\mathrm{pH}=11.26$ & $\mathrm{pH}=11.30$ & $\mathrm{pH}=11.68$ \\
$(10)$ & -37.4 & -42.3 & -48.4 & -56.2 \\
$(11)$ & -25.8 & -29.4 & -33.6 & -39.3 \\
$(12)$ & -17.7 & -20.9 & -24.8 & -30.0 \\
$(27)$ & -49.6 & -55.0 & -62.2 & -70.6 \\
$(28)$ & $-66.1+4 \mathrm{pH}$ & $-73.7+4 \mathrm{pH}$ & $-83.6+4 \mathrm{pH}$ & $-95.5+4 \mathrm{pH}$ \\
$(30)$ & $-230.3+18 \mathrm{pH}$ & $-233.3+18 \mathrm{pH}$ & $-244.1+18 \mathrm{pH}$ & $-176.6+18 \mathrm{pH}$ \\
\hline
\end{tabular}




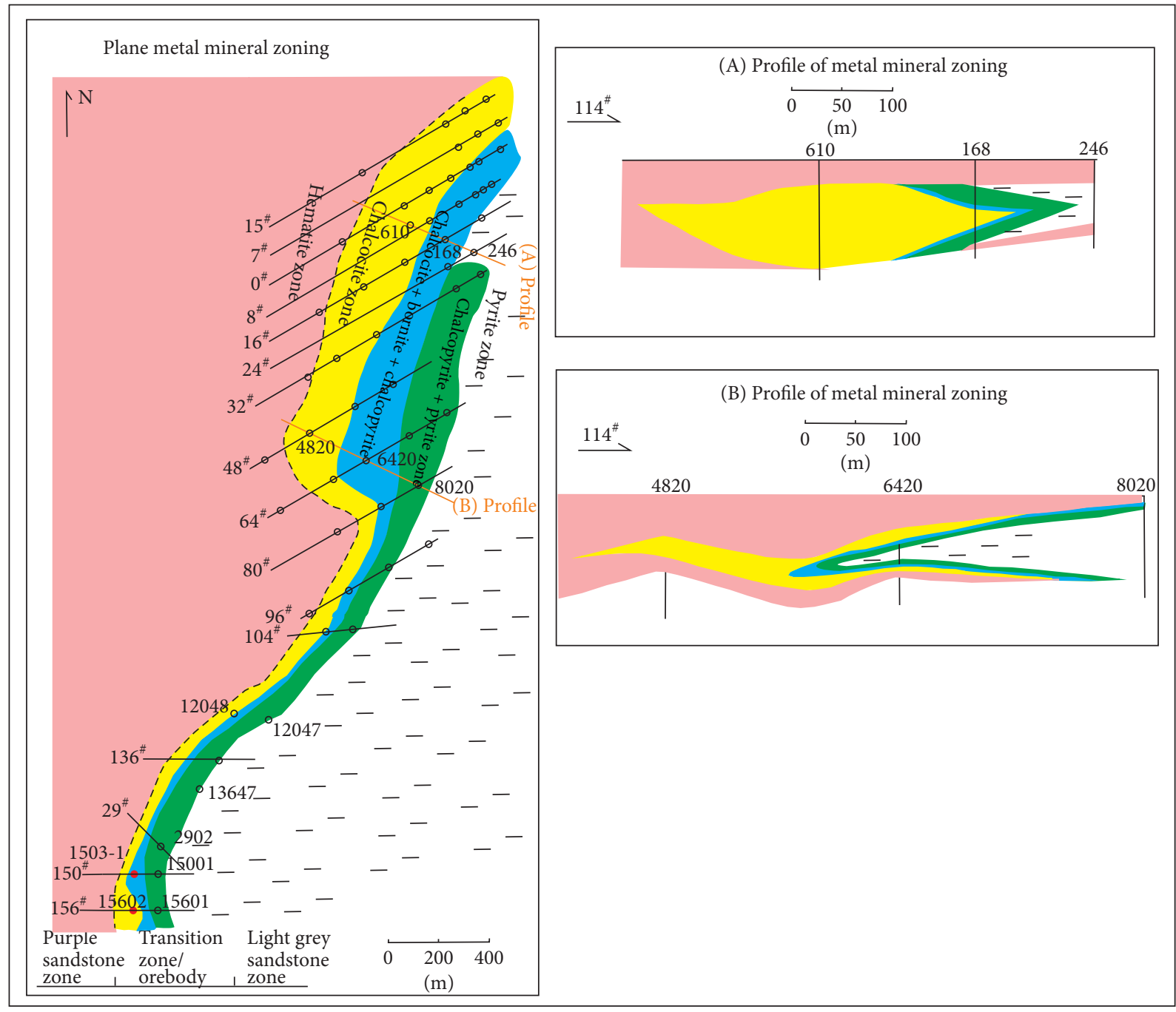

Hematite zone

Pyrite zone

Chalcocite + bornite + chalcopyrite zone

Chalcopyrite + pyrite zone

$\triangle A$ Location of the profile
${ }_{8020}$ Location of the drill and their numbers

24 Location of the exploratory and their numbers

,-1 The boundary line between the purple sandstone and the light grey sandstone

Chalcocite zone

Sampling location

FIGURE 6: Metal mineral zoning of Dayao copper deposit.

increases with temperature decreasing because of the precipitation of volatile components during the migration process of the ore-forming hydrothermal fluid. In addition, decrease in $\mathrm{HCl}$ and $\mathrm{H}_{2} \mathrm{O}$ contents could reduce metal carrying ability, leading to mineral precipitation.

(4) $\log f_{\mathrm{O}_{2}}$ has little effect on mineral precipitation. The range of $\log f_{\mathrm{O}_{2}}^{2}$ suitable for $\mathrm{FeS}_{2}$ formation is wide, but that of $\log f_{\mathrm{O} 2}$ suitable to form other minerals is basically the same.

The scope of $\mathrm{pH}$ for mineral precipitation mentioned above is in accordance with that reported by Zhao and Zhang [69]. For example, the scope of $\mathrm{pH}$ is $2.5 \sim 8$ for $\mathrm{Fe}^{2+}$ and $\mathrm{Cu}^{2+}$; both are amphoteric elements which migrate in dissolved state at strong acidic or alkaline conditions. Thus, $\mathrm{CuFeS}_{2}$ is precipitated in nearly neutral conditions. The scope of $\mathrm{pH}$ is $<2.5$ for $\mathrm{Cu}^{+}$, an alkaline element which has low electrovalence and great radius and is easy to migrate in acidic medium, so $\mathrm{Cu}_{2} \mathrm{~S}$ is easy to precipitate in alkaline condition. Because both bivalent copper and cuprous ions are present in $\mathrm{Cu}_{5} \mathrm{FeS}_{4}$, they are precipitated at neutral to alkaline conditions.

5.2. Constraints of $\log f_{S_{2}}$ and $\log f_{O_{2}}$ on Sulfide Precipitation. It is clear from Figure 9 and Table 5 that stable $\log f_{\mathrm{O}_{2}}{ }^{-}$ $\log f_{\mathrm{S}_{2}}$ range of the 22 kinds of minerals and their assemblage 
TABLE 4: Chemical reactions and $\log f_{\mathrm{O}_{2}}, \log f_{\mathrm{S}_{2}}$, and slope of chemical reactions at different temperature.

\begin{tabular}{|c|c|c|c|c|c|c|c|c|}
\hline \multirow{2}{*}{ Chemical reactions } & \multicolumn{2}{|c|}{$T=373 \mathrm{~K}$} & \multicolumn{2}{|c|}{$T=423 \mathrm{~K}$} & \multicolumn{2}{|c|}{$T=473 \mathrm{~K}$} & \multicolumn{2}{|c|}{$T=523 \mathrm{~K}$} \\
\hline & $\log f_{\mathrm{O} 2}$ & $\log f_{\mathrm{S} 2}$ & $\log f_{\mathrm{O} 2}$ & $\log f_{\mathrm{S} 2}$ & $\log f_{\mathrm{O} 2}$ & $\log f_{\mathrm{S} 2}$ & $\log f_{\mathrm{O} 2}$ & $\log f_{\mathrm{S} 2}$ \\
\hline (1) $3 \mathrm{Fe}+2 \mathrm{O}_{2}=\mathrm{Fe}_{3} \mathrm{O}_{4}$ & -69.1 & & -59.9 & & -52.7 & & -46.8 & \\
\hline (2) $2 \mathrm{Fe}_{3} \mathrm{O}_{4}+1 / 2 \mathrm{O}_{2}=3 \mathrm{Fe}_{2} \mathrm{O}_{3}$ & -53.7 & & -45.7 & & -39.3 & & -34.2 & \\
\hline (3) $\mathrm{Fe}+1 / 2 \mathrm{~S}_{2}=\mathrm{FeS}$ & & -37.9 & & -32.5 & & -28.3 & & -24.9 \\
\hline (4) $\mathrm{FeS}+1 / 2 \mathrm{~S}_{2}=\mathrm{FeS}_{2}$ & & -25.0 & & -20.5 & & -16.9 & & -14.0 \\
\hline (5) $3 \mathrm{FeS}+2 \mathrm{O}_{2}=\mathrm{Fe}_{3} \mathrm{O}_{4}+1 / 2 \mathrm{~S}_{2}$ & \multicolumn{8}{|c|}{$\tan \alpha=4 / 3, \alpha=53.1$} \\
\hline (6) $3 \mathrm{FeS}_{2}+2 \mathrm{O}_{2}=\mathrm{Fe}_{3} \mathrm{O}_{4}+3 \mathrm{~S}_{2}$ & \multicolumn{8}{|c|}{$\tan \alpha=2 / 3, \alpha=33.7$} \\
\hline (7) $2 \mathrm{FeS}_{2}+3 / 2 \mathrm{O}_{2}=\mathrm{Fe}_{2} \mathrm{O}_{3}+2 \mathrm{~S}_{2}$ & \multicolumn{8}{|c|}{$\tan \alpha=3 / 4, \alpha=36.9$} \\
\hline (8) $2 \mathrm{Cu}+1 / 2 \mathrm{O}_{2}=\mathrm{Cu}_{2} \mathrm{O}$ & -39.1 & & -33.6 & & -29.3 & & -25.9 & \\
\hline (9) $\mathrm{Cu}_{2} \mathrm{O}+1 / 2 \mathrm{O}_{2}=2 \mathrm{CuO}$ & -29.6 & & -24.8 & & -20.8 & & -17.7 & \\
\hline (10) $2 \mathrm{Cu}+1 / 2 \mathrm{~S}_{2}=\mathrm{Cu}_{2} \mathrm{~S}$ & & -34.3 & & -29.7 & & -26.1 & & -23.2 \\
\hline (11) $\mathrm{Cu}_{2} \mathrm{~S}+1 / 2 \mathrm{O}_{2}=\mathrm{Cu}_{2} \mathrm{O}+\mathrm{S}_{2}$ & \multicolumn{8}{|c|}{$\tan \alpha=1, \alpha=45$} \\
\hline (12) $\mathrm{Cu}_{2} \mathrm{~S}+1 / 2 \mathrm{O}_{2}=2 \mathrm{CuO}+\mathrm{S}_{2}$ & \multicolumn{8}{|c|}{$\tan \alpha=2, \alpha=63.4$} \\
\hline (13) $2 \mathrm{FeS}+5 \mathrm{CuFeS}_{2}+4 \mathrm{O}_{2}=\mathrm{Cu}_{5} \mathrm{FeS}_{4}+2 \mathrm{Fe}_{3} \mathrm{O}_{4}+4 \mathrm{~S}_{2}$ & \multicolumn{8}{|c|}{$\tan \alpha=1, \alpha=45$} \\
\hline (14) $3 \mathrm{FeS}+\mathrm{CuFeS}_{2}+2 \mathrm{O}_{2}=\mathrm{CuFeS}_{2}+\mathrm{Fe}_{3} \mathrm{O}_{4}+3 / 2 \mathrm{~S}_{2}$ & \multicolumn{8}{|c|}{$\tan \alpha=4 / 3, \alpha=53.1$} \\
\hline (15) $3 \mathrm{FeS}_{2}+\mathrm{CuFeS}_{2}+2 \mathrm{O}_{2}=\mathrm{CuFeS}_{2}+\mathrm{Fe}_{3} \mathrm{O}_{4}+3 \mathrm{~S}_{2}$ & \multicolumn{8}{|c|}{$\tan \alpha=2 / 3, \alpha=33.7$} \\
\hline (16) $\mathrm{FeS}_{2}+5 \mathrm{CuFeS}_{2}+\mathrm{S}_{2}=\mathrm{Cu}_{5} \mathrm{FeS}_{4}+5 \mathrm{FeS}_{2}$ & & -14.3 & & -12.7 & & -11.1 & & -8.6 \\
\hline (17) $\mathrm{Cu}_{2} \mathrm{~S}+2 \mathrm{Fe}_{3} \mathrm{O}_{4}+1 / 2 \mathrm{O}_{2}=\mathrm{Cu}_{2} \mathrm{~S}+3 \mathrm{Fe}_{2} \mathrm{O}_{3}$ & -42.4 & & -40.8 & & -39.3 & & -34.2 & \\
\hline (18) $2 \mathrm{FeS}_{2}+\mathrm{CuFeS}_{2}+3 / 2 \mathrm{O}_{2}=\mathrm{CuFeS}_{2}+\mathrm{Fe}_{2} \mathrm{O}_{3}+2 \mathrm{~S}_{2}$ & \multicolumn{8}{|c|}{$\tan \alpha=3 / 4, \alpha=36.7$} \\
\hline (19) $2 \mathrm{FeS}_{2}+\mathrm{Cu}_{5} \mathrm{FeS}_{4}+3 / 2 \mathrm{O}_{2}=\mathrm{Cu}_{5} \mathrm{FeS}_{4}+\mathrm{Fe}_{2} \mathrm{O}_{3}+2 \mathrm{~S}_{2}$ & \multicolumn{8}{|c|}{$\tan \alpha=3 / 4, \alpha=36.7$} \\
\hline (20) $\mathrm{Cu}_{2} \mathrm{~S}+\mathrm{Fe}_{2} \mathrm{O}_{3}+1 / 2 \mathrm{O}_{2}=\mathrm{Cu} 2 \mathrm{O}+\mathrm{Fe} 2 \mathrm{O} 3+\mathrm{S}_{2}$ & \multicolumn{8}{|c|}{$\tan \alpha=1, \alpha=45$} \\
\hline (21) $3 \mathrm{Cu}_{5} \mathrm{FeS}_{4}+2 \mathrm{O}_{2}=\mathrm{Cu}_{2} \mathrm{~S}+\mathrm{Fe}_{3} \mathrm{O}_{4}+9 / 4 \mathrm{~S}_{2}$ & \multicolumn{8}{|c|}{$\tan \alpha=8 / 9, \alpha=41.6$} \\
\hline (22) $5 \mathrm{CuFeS}_{2}+\mathrm{Fe}_{2} \mathrm{O}_{3}+15 / 4 \mathrm{O}_{2}=\mathrm{Cu}_{5} \mathrm{FeS}_{4}+7 / 2 \mathrm{Fe}_{2} \mathrm{O}_{3}+3 \mathrm{~S}_{2}$ & \multicolumn{8}{|c|}{$\tan \alpha=15 / 12, \alpha=51.3$} \\
\hline (23) $4 \mathrm{~S}_{2}=\mathrm{S}_{8}$ & & -8.2 & & -6.5 & & -5.1 & & -4.1 \\
\hline
\end{tabular}

TABLE 5: Comparison of $\log f_{\mathrm{O}_{2}}-\log f_{\mathrm{S}_{2}}$, redox block, lithology, and mineral assembly.

\begin{tabular}{|c|c|c|c|c|}
\hline Redox state block & $\begin{array}{l}\text { The area of approximate } \\
\text { trapezoid under the (8), } \\
\text { (11), and (12) balance lines } \\
\text { and coordinate axis }\end{array}$ & $\begin{array}{l}\text { The area of polygon } \\
\text { under the (3), (13), } \\
(20),(8),(11) \text {, and (12) } \\
\text { balance lines }\end{array}$ & $\begin{array}{l}\text { The area of approximate } \\
\text { triangle under the (5), (6), } \\
(7),(13) \text {, and (23) balance } \\
\text { lines }\end{array}$ & $\begin{array}{l}\text { The area of approximate } \\
\text { trapezoid under (3), (5), } \\
(6),(7) \text {, and (23) balance } \\
\text { lines and coordinate axis }\end{array}$ \\
\hline Lith & Purple & Amaranth & Pale red or light grey & Light grey off-white \\
\hline $\begin{array}{l}\text { Cementing patterns of } \\
\text { different type sandstones }\end{array}$ & $\begin{array}{l}\text { Ferruginous, calcium } \\
\text { argillaceous, which } \\
\text { contains a large quantity of } \\
\text { hematite, calcite, dolomite, } \\
\text { and clay mineral }\end{array}$ & $\begin{array}{l}\text { Ferruginous, calcium } \\
\text { argillaceous, which } \\
\text { contains a large } \\
\text { quantity of hematite, } \\
\text { calcite, dolomite, and } \\
\text { clay mineral } \\
\text { Copper sulfide } \\
\text { mineral assemblage }\end{array}$ & $\begin{array}{c}\text { Copper sulfide mineral } \\
\text { assemblage }\end{array}$ & $\begin{array}{c}\text { Principal siliceous } \\
\text { cementation which } \\
\text { contains recrystallization, } \\
\text { secondary overgrowing } \\
\text { quartz/pyrite, etc. }\end{array}$ \\
\hline Redox zoning & Strong oxidizing zone & Oxidizing zone & $\begin{array}{l}\text { Oxidizing-reducing } \\
\text { transitive zone }\end{array}$ & Reducing zone \\
\hline $\begin{array}{l}\text { Typical mineral assemblage } \\
\text { (the minerals marked by } \\
\text { italic are the typical } \\
\text { minerals for each zoning) }\end{array}$ & $\begin{array}{c}\text { Iron and copper oxide such } \\
\text { as hematite, } \\
\text { cuprite, and tenorite }\end{array}$ & $\begin{array}{l}\text { Iron oxide }+ \text { copper } \\
\text { sulfide such as } \\
\text { hematite, magnetite, } \\
\text { and chalcocite }\end{array}$ & $\begin{array}{l}\text { Iron oxide + copper sulfide } \\
\text { such as hematite, } \\
\text { magnetite, bornite, and } \\
\text { chalcopyrite }\end{array}$ & $\begin{array}{l}\text { Iron and copper sulfide } \\
\text { such as chalcopyrite, } \\
\text { pyrrhotite, and pyrite }\end{array}$ \\
\hline
\end{tabular}

as well as the trend of the redox block distribution by parsing the phase diagram. By comparing and analyzing the trend of the redox block distribution in the phase diagram and the mineral assemblage zoning based on the redox trend in Dayao copper deposit, one could find that the permutation and assemblage of mineral in the phase diagram are consistent with the redox trend which reflects the mineral zoning on the geological occurrence (Table 5). Taking $T=$ $423 \mathrm{~K}$ as an example, the fact can be explained as follows (Figure 9).

(1) At the same temperature, each mineral and its assemblage have their own respective scopes of $\log f_{\mathrm{O}_{2}}$ and $\log f_{\mathrm{S}_{2}}$, 

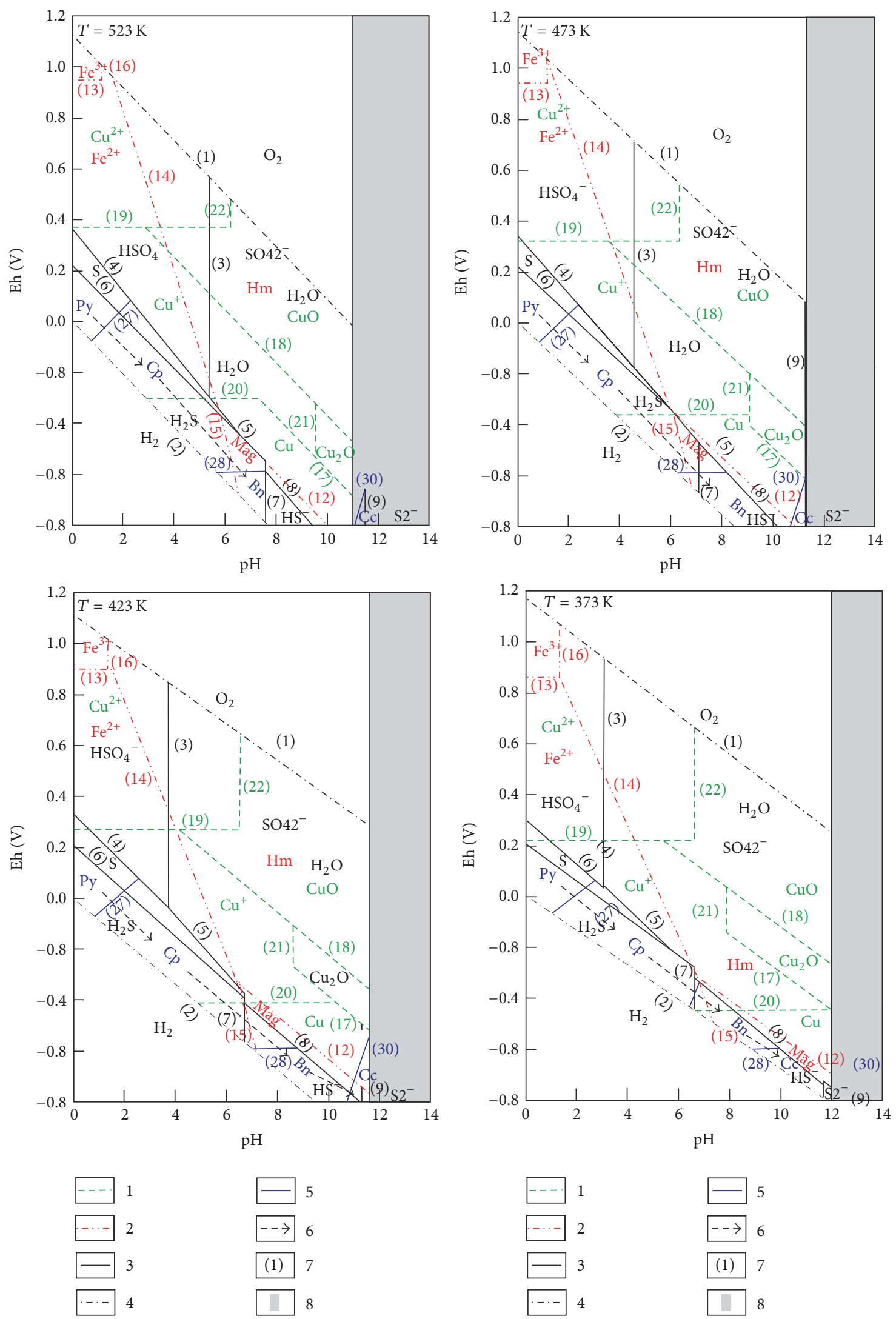

Figure 7: pH-Eh diagram of $\mathrm{Cu}-\mathrm{O}_{2}-\mathrm{S}$-Fe system at $373 \mathrm{~K}-523 \mathrm{~K}\left(\sum \mathrm{S}=0.02 \mathrm{~mol} / \mathrm{L}, \sum \mathrm{Fe}=10^{-8} \mathrm{~mol} / \mathrm{L}, \sum \mathrm{Cu}=10^{-8} \mathrm{~mol} / \mathrm{L}\right)$. 1: balance line of $\mathrm{Cu}$; 2: balance line of $\mathrm{Fe}$; 3: balance line of $\mathrm{S}$; 4: balance line of $\mathrm{H}_{2} \mathrm{O}$; 5 : balance line of sulfide; 6: order of sulfide precipitation; 7: number of chemical equations in Table 2; 8: nonexistence in fact because of $\mathrm{K}_{\mathrm{H} 2 \mathrm{O}}$ at the different temperatures. Py: pyrite; Cp: chalcopyrite; Bn: bornite; Cc: chalcocite; Hm: hematite; Mag: magnetite. 

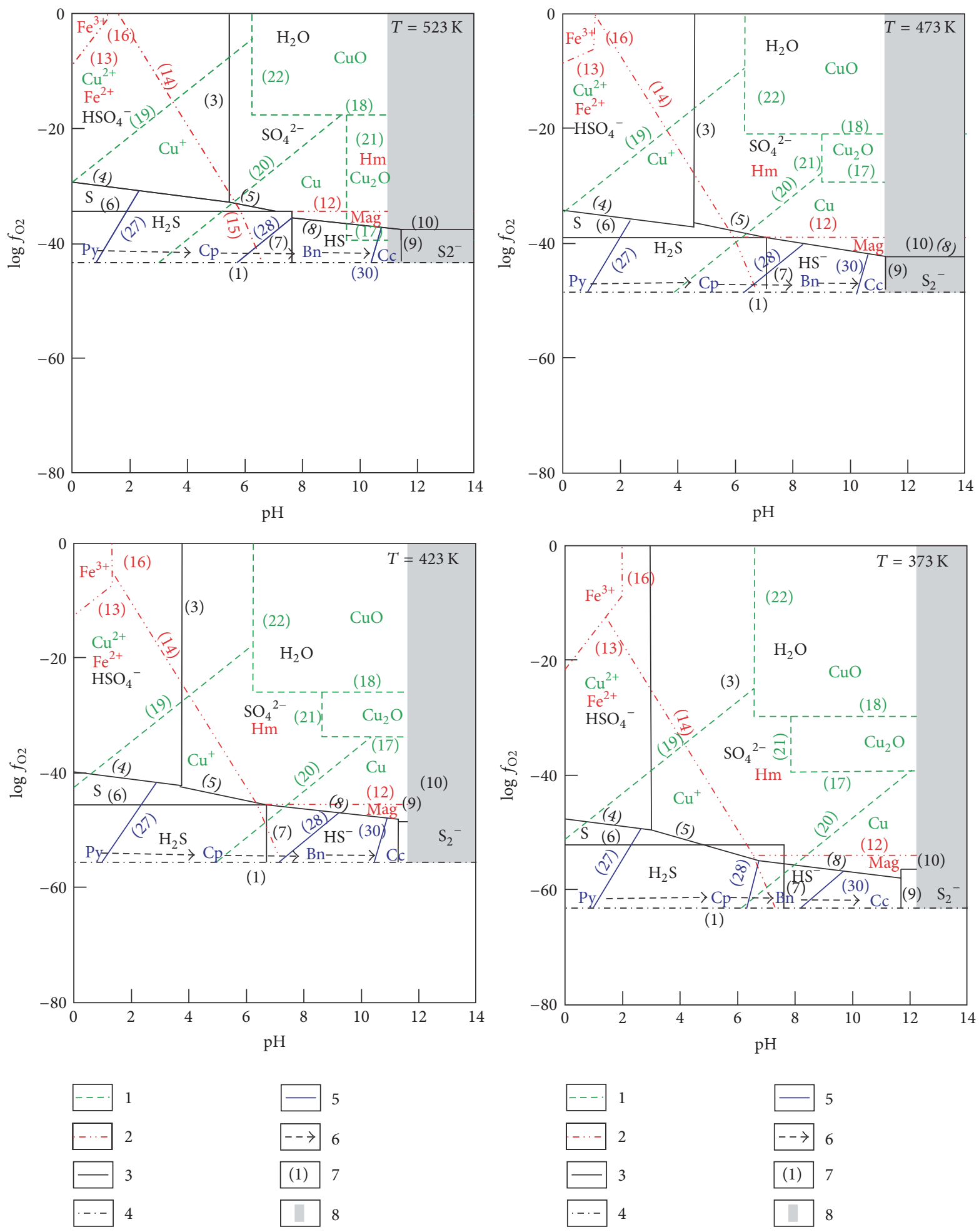

Figure 8: pH-Eh diagram of $\mathrm{Cu}$ - $\mathrm{O}_{2}-\mathrm{S}$ - Fe system at $373 \mathrm{~K}-523 \mathrm{~K}\left(\sum \mathrm{S}=0.02 \mathrm{~mol} / \mathrm{L}, \sum \mathrm{Fe}=10^{-8} \mathrm{~mol} / \mathrm{L}, \sum \mathrm{Cu}=10^{-8} \mathrm{~mol} / \mathrm{L}\right) .1$ : balance line of $\mathrm{Cu} ; 2$ : balance line of $\mathrm{Fe}$; 3: balance line of $\mathrm{S} ; 4$ : balance line of $\mathrm{H}_{2} \mathrm{O}$; 5 : balance line of sulfide; 6: order of sulfide precipitation; 7: number of chemical equations in Table 2; and 8: nonexistence in fact because of $\mathrm{K}_{\mathrm{H} 2 \mathrm{O}}$ at the different temperatures. Py: pyrite; Cp: chalcopyrite; Bn: bornite; Cc: chalcocite; Hm: hematite; and Mag: magnetite. 
TABLE 6: The $\mathrm{pH}$, Eh $\log f_{\mathrm{O}_{2}}$, and $\log f_{\mathrm{S}_{2}}$ range of mineral assemblage at different temperature.

\begin{tabular}{|c|c|c|c|c|}
\hline & $\mathrm{FeS}_{2}$ & $\mathrm{CuFeS}_{2}$ & $\mathrm{Cu}_{5} \mathrm{FeS}_{4}$ & $\mathrm{Cu}_{2} \mathrm{~S}$ \\
\hline \multicolumn{5}{|l|}{$373 \mathrm{~K}$} \\
\hline Eh & $(-0.07,0.33)$ & $(-0.61,0.06)$ & $(-0.43,0.06)$ & $(-0.80,-0.33)$ \\
\hline $\mathrm{pH}$ & $(0,2.7)$ & $(1,10)$ & $(1,10)$ & $(6.4,12.2)$ \\
\hline $\log f_{\mathrm{O} 2}$ & $(-63.1,-47.5)$ & $(-63.1,-55)$ & $(-63.1,-56.8)$ & $(-63.14,-56.2)$ \\
\hline $\log f_{\mathrm{S} 2}$ & $(-25.0,-8.7)$ & $(-38.4,-25.0)$ & $(-18.2,-8.7)$ & $(-34.3,-8.7)$ \\
\hline \multicolumn{5}{|l|}{$423 \mathrm{~K}$} \\
\hline Eh & $(-0.07,0.33)$ & $(-0.59,0.07)$ & $(-0.80,-0.59)$ & $(-0.80,0.12)$ \\
\hline $\mathrm{pH}$ & $(0,2.6)$ & $(0.8,8.8)$ & $(7,10.7)$ & $(10.7,11.6)$ \\
\hline $\log f_{\mathrm{O} 2}$ & $(-55.5,-39.8)$ & $(-55.5,-41.7)$ & $(-55.5,-46.1)$ & $(-55.5,-48)$ \\
\hline $\log f_{\mathrm{S} 2}$ & $(-20.5,-6.5)$ & $(-32.5,-20.5)$ & $(-12.7,-6.5)$ & $(-29.7,-6.5)$ \\
\hline \multicolumn{5}{|l|}{$473 \mathrm{~K}$} \\
\hline Eh & $(-0.08,0.34)$ & $(-0.59,0.07)$ & $(-0.80,-0.59)$ & $(-0.80,-0.08)$ \\
\hline $\mathrm{pH}$ & $(0,2.4)$ & $(0.8,8.2)$ & $(6.3,10.1)$ & $(10.1,11.3)$ \\
\hline $\log f_{\mathrm{O} 2}$ & $(-48.6,-34.1)$ & $(-48.6,-36.4)$ & $(-48.6,-41)$ & $(48.6,-42.3)$ \\
\hline $\log f_{\mathrm{S} 2}$ & $(-16.9,-5.1)$ & $(-28.3,-16.9)$ & $(-11.1,-5.1)$ & $(-26.1,-5.1)$ \\
\hline \multicolumn{5}{|l|}{$523 \mathrm{~K}$} \\
\hline Eh & $(-0.08,0.34)$ & $(-0.58,0.08)$ & $(-0.80,0.59)$ & $(-0.80,-0.20)$ \\
\hline $\mathrm{pH}$ & $(0,2.3)$ & $(0.7,7.6)$ & $(7.6,9.4)$ & $(9.4,11.0)$ \\
\hline $\log f_{\mathrm{O} 2}$ & $(-43.4,-29.3)$ & $(-43.4,-30.8)$ & $(-43.4,-35.8)$ & $(-43.4,-37)$ \\
\hline $\log f_{\mathrm{S} 2}$ & $(-14.0,-4.1)$ & $(-24.9,-14.0)$ & $(-8.6,-4.1)$ & $(-23.2,-4.1)$ \\
\hline
\end{tabular}

TABLE 7: The features of mineral zoning.

\begin{tabular}{lccccc}
\hline & $\mathrm{FeS}_{2}$ & $\mathrm{CuFeS}_{2}$ & $\mathrm{Cu}_{5} \mathrm{FeS}_{4}$ & $\mathrm{Cu}_{2} \mathrm{~S}^{2-}$ & $\mathrm{Fe}_{2} \mathrm{O}_{3}+\mathrm{Cu}^{2}$ \\
\hline $\mathrm{S}$ system & $\mathrm{H}_{2} \mathrm{~S}$ & $\mathrm{H}_{2} \mathrm{~S}+\mathrm{HS}^{-}$ & $\mathrm{H}_{2} \mathrm{~S}+\mathrm{HS}^{-}$ & $\mathrm{HS}^{-}+\mathrm{S}^{2-}$ & $\mathrm{SO}_{4}{ }^{2-}$ \\
$\mathrm{pH}$ & Acid & Weak acid neutral & Neutral-weak alkalinity & Alkalinity & Weak acid alkalinity \\
Eh & Weak reduction & Reduction & Reduction & Reduction & Oxidation \\
$f_{\mathrm{O}_{2}}$ & Medium & Medium & Medium & Medium & Medium-high \\
$f_{\mathrm{S} 2}$ & Medium-high & Medium & Medium-high & Medium & Medium \\
Cement & Quartz & Quartz + carbonate & Quartz + carbonate & Quartz + carbonate Carbonate + clay \\
Temperature variation & Medium & Medium-low temperature & Medium-low & Low & Medium \\
\hline
\end{tabular}

indicating that the ranges of $\log f_{\mathrm{O}_{2}}$ and $\log f_{\mathrm{S}_{2}}$ control the distribution of minerals and their assemblage. The cementing patterns of different type sandstones, mineral assemblage features, and obvious differences among the oxidizing-reducing environments are corresponding to the zoning features of the mineral assemblage (Table 5).

(2) When temperature falls, the scopes of $\log f_{\mathrm{O}_{2}}$ and $\log f_{\mathrm{S}_{2}}$ of mineral precipitation also decrease correspondingly (Figure 9), and the redox effect becomes weaker. The mineral stability range (the block occupied in the phase diagram) shifts towards native $\mathrm{Fe}$ and $\mathrm{Cu}$ with temperature declining. Oxidation-reduction area of the transition block occupied by chalcocite is always large, indicating that chalcocite precipitated fugacity has a very wide range.

(3) Zones of $\mathrm{Cu}_{2} \mathrm{~S}$ minerals, bornite, chalcopyrite, and pyrite are arranged across redox boundaries with chalcocite on the oxidized side and pyrite on the reduced side. It is manifested by the light-purple interactive zone that the lower right area in Figure 9 is purple-amaranthine sandstone zone with abundant oxide minerals; the upper left area is light grey off-white sandstone zone with abundant reductive minerals; and nearly triangular-shaped zone between the above two zones is the light-purple interactive zone. Therefore, the mineral assemblages along with the evolution from the lower right strong oxidizing zone towards the upper left reducing zone in Figure 9 have the following main features: strong oxidizing zone, oxidizing zone, oxidizing-reducing transitive zone, and weak reducing zone to reducing zone. Sulfur and oxygen fugacity, lithology, mineral assemblage, and redox blocks have one-to-one corresponding relationship (Table 5).

\section{Discussions}

6.1. The Correspondence between Thermodynamic Phase Diagram and Geological Features. From the three phase diagrams (Figures 7-9), we can obtain Tables 6 and 7 and listed 

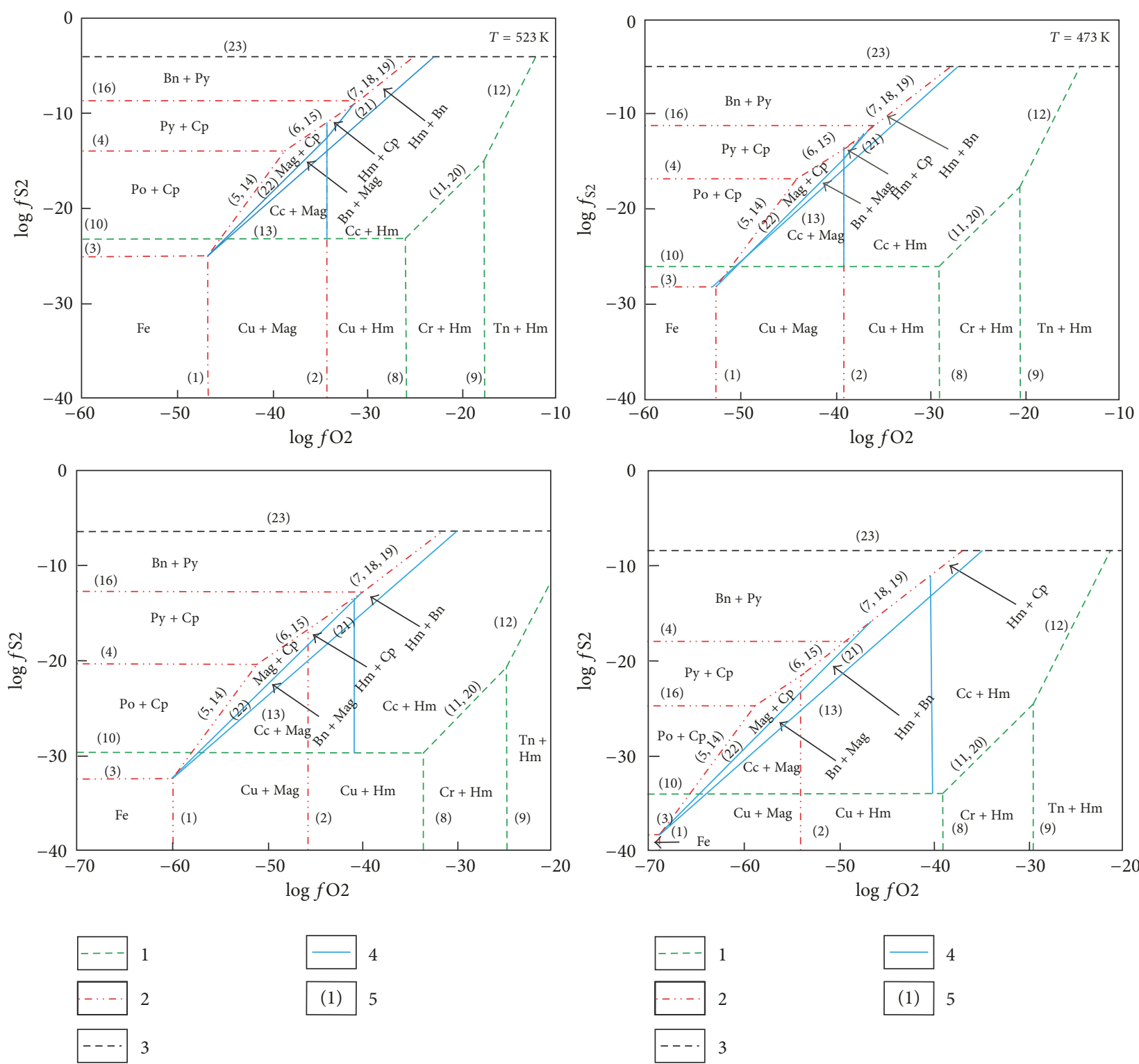

Figure 9: $\log f_{\mathrm{O}_{2}}-\log f_{\mathrm{S}_{2}}$ diagram of $\mathrm{Cu}-\mathrm{O}_{2}-\mathrm{S}$-Fe system at $373 \mathrm{~K}-523 \mathrm{~K}$. 1: balance line of Cu; 2: balance line of Fe; 3: balance line of S; 4: balance line between sulfide and oxide; 5: number of chemical equations in Table 4; Py: pyrite; Cp: chalcopyrite; Bn: bornite; Cc: chalcocite; Hm: hematite; Mag: magnetite; Cr: cuprite; and Tn: tenorite.

the $\mathrm{pH}, \mathrm{Eh}, \log f_{\mathrm{O}_{2}}$, and $\log f_{\mathrm{S}_{2}}$ conditions for the precipitation of each sulfide mineral. The geological features of Dayao copper deposit have been testified in the thermodynamic calculation and the phase diagrams (Figures 7, 8, and 9 and Tables 5, 6, and 7).

During the early stage of the diagenetic period, recrystallization of quartz and extensive pyritization took place and the purple sandstone was discolored and changed into the light grey sandstone zone in the red-bed type copper deposits, Chuxiong basin. During the reformatting diagenetic period, silicification developed and changed the purple sandstone into discolor and formed off-white quartz sandstone or dissolved and transported the copper from the sandstone body that contains metal elements (or sandstone ore body). Both two processes could take place in (weak) acidic conditions (Table 7).

Theoretic results and phase diagrams are consistent with both the macrogeological and microgeological characteristics of copper mineralization. Macroscopically (Figures 3 and 6), the mineral zoning is characterized as light-purple interactive zone and mainly indicates the cementation pattern of the sandstones and the features of the mineral assemblage (Tables 5 and 7). Purple-red sandstone cement belonged to iron and calcium mud, which contains a large amount of hematite, calcite, dolomite, and clay minerals, representing an oxidizing and alkaline environment. The light greygreyish white sandstone mainly consisted of siliceous cement, containing recrystallization and overgrowth of quartz and 


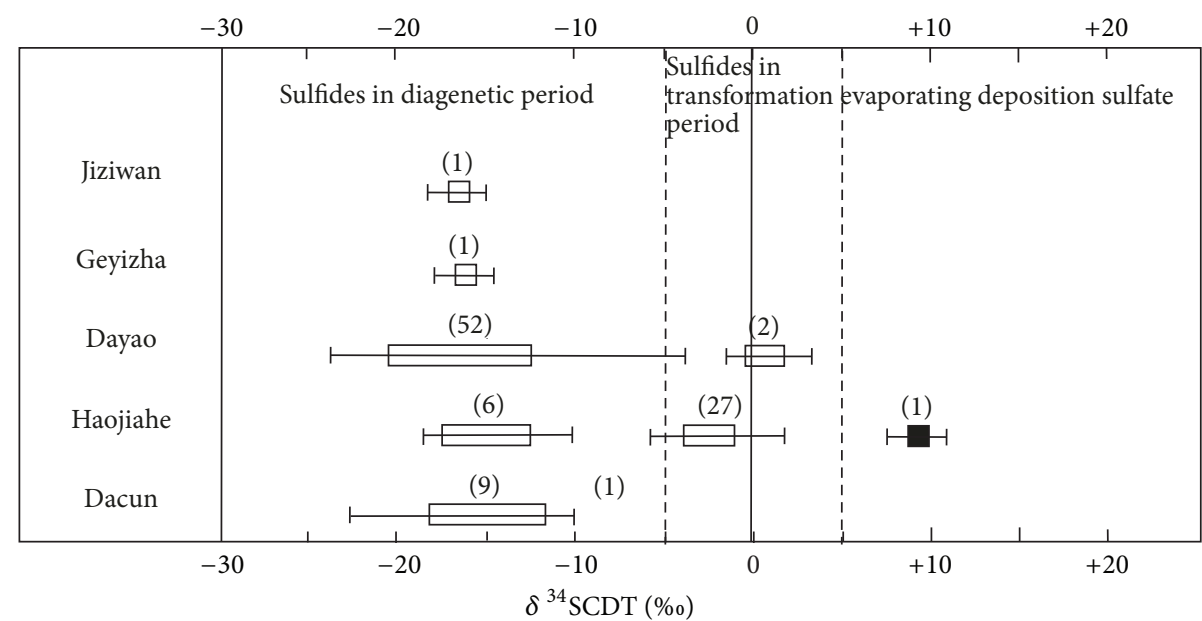

FIGURE 10: Distribution of sulfur isotope compositions for sulfides from the red-bed type copper deposits in Chuxiong basin. Sources of data are as follows: [51, 70-75]. The number of parentheses is the number of samples.

pyrite and other minerals, which represents a reduction of acidic medium environment. The zone of a large number of copper sulfide between purple-red sandstone and the light grey-greyish white sandstone represents the redox and acidbase transition zone.

\subsection{Interpretation of Mineral Zoning and Metallogenic Process} by Thermodynamic Phase Diagrams. A large number of studies have shown that the precipitation of sulfide minerals in SSC copper deposits is caused by reduction $[1,2,6,9,25,26$, $28,46,76-86]$, which is true for the red-bed copper deposit in Chuxiong basin [37, 48-50].

The Chuxiong basin is a Mesozoic and Cenozoic red basin with copper and polymetallic, coal, oil, and gas formations and their associated deposits [87]. The occurrence and development of paleo-continental rift in the Kangdian region brought up a Chuxiong basin, deposited cycles and ore-bearing formations of coal, evaporate, and copper, and formed the associated organic $\left(\mathrm{T}_{3}-\mathrm{J}\right)$, copper $\left(\mathrm{K}_{2}\right)$, and saline $\left(\mathrm{K}_{2}-\mathrm{E}\right)$ deposits [87]. There commonly exist veinlike, spotted, and cloud dry asphalt in host rock, structures, especially in rich ores, with organic carbon showing positive correlation with $\mathrm{Cu}$ and $\mathrm{Ag}$ content in Haojiahe deposit [70]. Geochemical studies of the strata by [70] show that in Mesozoic strata of the region copper abundance tends to increase, whereas organic carbon abundance tends to decrease from the lower part upward. Studies on organic geochemistry indicate that the origin, type, and maturity of organic matter are different among coal-bearing, copper-bearing, and evaporate formations in the Mesozoic continental Chuxiong basin [88]. Many scholars believed that organic matter and the evaporates played an important role for the red-bed type copper deposits in Chuxiong basin $[89,90]$.

Previous studies have shown that the $\delta^{34} S$ values of sulfides from the red-bed type copper deposits in Chuxiong basin are mainly distributed in two intervals [51, 70-75] (Figure 10). It shows that $\delta^{34} \mathrm{~S}$ values of sulfides in diagenetic period vary between $-25 \%$ and $-5 \%$ in all of the ore deposits, which is essentially the same as the $\delta^{34} \mathrm{~S}$ values of sulfides which varied in the range from $-21.7 \%$ o to $-8.4 \%$ o of samples (1)-(3) in the bottom part of the Kupferschiefer profile from the Sangerhausen basin [91]. Upon TSR, the effect of isotopic fractionation is low and the resulting sulfides have values above $-20 \%$ [92]. The $\delta^{34} \mathrm{~S}$ values of sulfides in diagenetic period from the red-bed type copper deposits in Chuxiong basin are in accordance with a contribution of TSR to sulfide precipitation. The distribution range of $\mathrm{S}$ isotopic compositions of sulfides in transformation period are entirely different, as shown in Figure 10, varying between $-5 \%$ and $5 \%$ in Dayao and Haojiahe ore deposits. This indicates that, in addition to sulfate reduction, the sulfur of deep seated magma source is involved in mineralization in these two deposits.

Han et al. [27] proposed that coal-copper-salt three-color sedimentary formation and basin fluid were formed during the Middle and Late Yanshan Period. The fluids Cu-bearing from basin basement ascended along the faults, derived the organic matter from the coal bed, mobilized the copper from the preexisting stratiform copper deposits and strata, and formed the reductive fluid rich in $\mathrm{Cu}$. The oxidative fluid of high salinity, which resulted from deep cycling of meteoric water and leaching of gypsum bed mixed the reductive fluid rich in $\mathrm{Cu}$ and caused intense redox reaction. $\mathrm{SO}_{4}{ }^{2-}$ was reduced into $\mathrm{H}_{2} \mathrm{~S}$ that reacted with copper to form the orebodies.

Combining the study of the phase diagrams (Figures 7-9 and Tables 5-7) and the deposit geologic features can better explain the reason for the mineral zoning. We inferred that the formation of the red-bed copper deposit in Chuxiong basin experienced the following processes.

During the sedimentation-diagenesis metallogenic epoch, the reducing fluid that contains copper from basin basement migrated towards the oxidizing purple sandstone that contains ferruginous and calcium argillaceous cements in the permeable stratum of the sandstone and shale. Water-rock interactions occurred between the fluid and 
the purple sandstone, changed the purple sandstone into light grey sandstone containing siliceous calcium cements, and formed the recrystallized or secondary growth quartz sandstone. Meanwhile, the redox, double decomposition, and replacement reactions took place in the ore body that is close to the light grey zone within the light-purple transitive zone.

(1) Formation of Pyrite Zone. Initially, the fluid containing a large amount of reducing constituent content is characterized as high temperature and low $\mathrm{pH}$. The hematite and magnetite in the purple sandstone were reduced into pyrite (reactions (6) and (7) in Table 4). The conditions for pyrite formation are acid, weak reduction, and medium $\log f_{\mathrm{S} 2}$.

(2) Formation of Chalcopyrite Zone. Because of the low $\mathrm{pH}$ and large amount of copper in fluid, the new formed pyrite reacts with $\mathrm{H}^{+}$and $\mathrm{Cu}^{2+}$ (reaction (27) in Table 2) to produce chalcopyrite. Therefore, the formation of chalcopyrite resulted in the increase of fluid $\mathrm{pH}$. The conditions for chalcopyrite formation are weak acid neutral, reduction, and medium $\log f_{\mathrm{S}_{2}}$.

(3) Formation of Bornite Zone. Because the formation of chalcopyrite is the acid consumption reaction, fluid acidity became neutral-weak alkalinity. Partial chalcopyrite is metasomatic to form bornite (reaction (28) in Table 2). The conditions for bornite formation are neutral-weak alkalinity, reduction, and medium-high $\log f_{\mathrm{S} 2}$.

(4) Formation of Chalcocite Zone. Along with the migration of fluid, the release of pressure makes volatile components separate out continuously, with decrease in some components, such as $\mathrm{HCl}$ and $\mathrm{H}_{2} \mathrm{O}$, and increase in the alkalinity of fluid. Addition to chalcocite on a wide range of sulfur and oxygen fugacity conditions can precipitate when the sulfur fugacity cannot meet the precipitation conditions of bornite, chalcopyrite, and chalcocite precipitate. The conditions for its formation are alkalinity, reduction, and medium $\log f_{\mathrm{S}_{2}}$.

Therefore, the mineral zoning is mainly controlled by the geochemical environment. Among the various physical and chemical conditions, $\mathrm{pH}$ is the vital factors controlling the order of different sulfide precipitation and explaining mineral zoning. The Eh and $f_{\mathrm{S}_{2}}$ determine the precipitation interval of sulfides, while $f_{\mathrm{O}_{2}}$ has little effect on mineral precipitation.

\section{Conclusions}

The calculations of the Eh, $\mathrm{pH}, \log f_{\mathrm{S}_{2}}$, and $\log f_{\mathrm{O}_{2}}$ within the principal metallogenic temperature of the Dayao redbed type copper deposits and the analysis of phase diagrams resulted in the following conclusions:

(1) The zoning pattern and mineral assemblage shown in the phase diagram are in accordance with the macroscopic and microscopic geological features of the deposits.

(2) The temperature variation has almost no impact on the $\mathrm{Eh}$ and $\mathrm{pH}$ of $\mathrm{FeS}_{2}$ and $\mathrm{Cu}_{2} \mathrm{~S}$ precipitation. Although the $\mathrm{Eh}$ is almost not affected with the falls of temperature for $\mathrm{CuFeS}_{2}$ and $\mathrm{Cu}_{5} \mathrm{FeS}_{4}$ precipitation, $\mathrm{CuFeS}_{2}$ and $\mathrm{Cu}_{5} \mathrm{FeS}_{4}$ precipitate with $\mathrm{pH}$ increasing. The value scope of $\log f_{\mathrm{O}_{2}}$ and $\log f_{\mathrm{S}_{2}}$ of the mineral precipitation decreases correspondingly with temperature decreasing.

(3) The scope of $\log f_{\mathrm{O}_{2}}$ and $\log f_{\mathrm{S}_{2}}$ of chalcocite is relatively wide. Because $\mathrm{S}^{2-}$ can only exist stably in hydrothermal fluid below $473 \mathrm{~K}$, the forming temperature of chalcocite is below $473 \mathrm{~K}$. This explains why the chalcocite is the main mineral of the red-bed type that formed at low temperature.

(4) Among the various physical and chemical conditions, $\mathrm{pH}$ is the vital factors controlling the order of different sulfide precipitation and explaining mineral zoning. The Eh and $f_{\mathrm{S}_{2}}$ determine the precipitation interval of sulfides, while $f_{\mathrm{O}_{2}}$ has little effect on mineral precipitation.

Since this paper only discussed the restrictions of Eh, $\mathrm{pH}, \log f_{\mathrm{O}_{2}}$, and $\log f_{\mathrm{S}_{2}}$, which have played roles in elements migration and precipitation. The problems regarding temperature, pressure, water-rock reaction, migration of copper and iron in hydrothermal system, migration pattern, and driving pattern of fluid remained for the future research.

\section{Conflicts of Interest}

The authors declare that they have no conflicts of interest.

\section{Acknowledgments}

This study was supported jointly by the National Natural Science Foundation of China (nos. U1133602 and 41572060), China Postdoctoral Science Foundation (2017M610614), projects of YM Lab (2011) and Innovation Team of Yunnan Province and KMUST (2008 and 2012), and Yunnan and Kunming University of Science and Technology Postdoctoral Sustentation Fund.

\section{References}

[1] M. Hitzman, R. Kirkham, D. Broughton, J. Thorson, and D. Selley, "The sediment-hosted stratiform copper ore system," Economic Geology, vol. 100, pp. 609-642, 2005.

[2] M. W. Hitzman, D. Selley, and S. Bull, "Formation of sedimentary rock-hosted stratiform copper deposits through earth history," Economic Geology, vol. 105, no. 3, pp. 627-639, 2010.

[3] P. Muchez, A.-S. André-Mayer, H. A. El Desouky, and L. Reisberg, "Diagenetic origin of the stratiform $\mathrm{Cu}-\mathrm{Co}$ deposit at Kamoto in the Central African Copperbelt," Mineralium Deposita, vol. 50, no. 4, pp. 437-447, 2015.

[4] S. N. Sadati, M. Yazdi, J. Mao et al., "Sulfide mineral chemistry investigation of sediment-hosted stratiform copper deposits, Nahand-Ivand area, NW Iran," Ore Geology Reviews, vol. 72, pp. 760-776, 2016.

[5] H. Azaraien, J. Shahabpour, and B. Aminzadeh, "Metallogenesis of the sediment-hosted stratiform $\mathrm{Cu}$ deposits of the Ravar Copper Belt (RCB), Central Iran," Ore Geology Reviews, vol. 81, pp. 369-395, 2017.

[6] R. V. Kirkham, "Distribution, settings, and genesis of sedimenthosted stratiform copper deposits," Geological Association of Canada Special Paper, vol. 36, pp. 3-38, 1989.

[7] R. V. Kirkham, J. J. Carriere, R. M. Laramee, and D. F. Garson, "Global distribution of sediment-hosted stratiform copper 
deposits and occurrences," Geological Survey of Canada, no. 2915b, 266 pages, 1994.

[8] A. C. Brown, "A process-based approach to estimating the copper derived from red beds in the sediment-hosted stratiform copper deposit model," Economic Geology, vol. 104, no. 6, pp. 857-868, 2009.

[9] A. B. Kampunzu, J. L. H. Cailteux, A. F. Kamona, M. M. Intiomale, and F. Melcher, "Sediment-hosted $\mathrm{Zn}-\mathrm{Pb}-\mathrm{Cu}$ deposits in the Central African Copperbelt," Ore Geology Reviews, vol. 35, no. 3-4, pp. 263-297, 2009.

[10] T. J. Bornhorst and W. C. Williams, "The mesoproterozoic copperwood sedimentary rock-hosted stratiform copper deposit, upper Peninsula, MI," Economic Geology, vol. 108, no. 6, pp. 1325-1346, 2013.

[11] C. D. Taylor, J. D. Causey, P. D. Denning et al., "Descriptive models, grade-tonnage relations, and databases for the assessment of sediment-hosted copper depositswith emphasis on deposits in the central african copperbelt, democratic republic of the congo and zambia," Scientific Investigations Report 2010-5090-J, pp. 1154, 2013.

[12] D. H. Zhang, B. Xiao, and C. Zhang, "Geological features and exploration prospects of th sediment-hosted stratiform coppercobalt deposits in zambia," Geology \& Exploration, vol. 49, pp. 577-588, 2013.

[13] S. Hassanpour and S. Senemari, "Mineralogy and geochemistry studies of the Sorkheh sediment-hosted stratiform copper (SSC) deposit, NW Iran," Iranian Journal of Earth Sciences, vol. 7, no. 2, pp. 89-105, 2015.

[14] A. L. Rainoldi, M. Franchini, A. Boyce, J. Pons, A. Giusiano, and N. Cesaretti, The role of hydrocarbons in the genesis of the sediment-hosted stratiform copper deposits, Neuquén Basin (Argentina), Sga Biennial Meeting, 2015.

[15] S. Rajabpour, A. Abedini, S. Alipour, B. Lehmann, and S.Y. Jiang, "Geology and geochemistry of the sediment-hosted Cheshmeh-Konan redbed-type copper deposit, NW Iran," Ore Geology Reviews, vol. 86, pp. 154-171, 2017.

[16] D. Selley, D. Broughton, R. Scott et al., "A new look at the geology of the Zambian Copperbelt," Society of Economic Geologists Inc, vol. 100, pp. 965-1000, 2005.

[17] R. N. Volodin, V. S. Chechetkon, and Y. V. Bogdanov, "The Udokan cupriferous sandstones deposit (eastern Siberia)," Geology of Ore Deposits, vol. 36, pp. 1-25, 1994.

[18] Z. Sawlowicz, "REE and their relevance to the development of the Kupferschiefer copper deposit in Poland," Ore Geology Reviews, vol. 55, no. C, pp. 176-186, 2013.

[19] R. H. Carpenter, "Some vein-wall rock relationships in the white pine mine, ontonagon co., Michigan," Economic Geology, vol. 58, no. 5, pp. 643-666, 1963.

[20] D. E. White, "Saline Waters of Sedimentary Rocks: abstract," American Association of Petroleum Geologists, vol. 47, 1963.

[21] A. C. Brown, "Zoning in the white pine copper deposit, ontonagon county, michigan," Economic Geology, vol. 66, no. 4, pp. 543-573, 1971.

[22] D. P. Cox, D. A. Lindsey, D.A. Singer, and M. F. Diggles, "Sediment hosted copper deposits of the world: Deposit model sand database," U.S. Geological Survey Open File Report pp. 153,2003 .

[23] G. Chen, B. Xia, Y. Wu, G. Tu, and H. Yu, "The metallogenic mechanism of the sandstone-type copper deposits in the Chuxiong Basin, Yunnan Province," Science China Earth Sciences, vol. 43, pp. 263-272, 2000.
[24] Z. K. Huang, Z. Bai, Y. S. ZHu, H. Z. Wang, and X. Z. Shang, Copper deposits in China, Geological Publishing House, Beijing, 2001.

[25] J. L. H. Cailteux, A. B. Kampunzu, C. Lerouge, A. K. Kaputo, and J. P. Milesi, "Genesis of sediment-hosted stratiform copper-cobalt deposits, central African Copperbelt," Journal of African Earth Sciences, vol. 42, no. 1-5, pp. 134-158, 2005.

[26] A. B. Kampunzu, J. L. H. Cailteux, B. Moine, and H. N. B. T. Loris, "Geochemical characterisation, provenance, source and depositional environment of 'Roches Argilo-Talqueuses' (RAT) and Mines Subgroups sedimentary rocks in the Neoproterozoic Katangan Belt (Congo): Lithostratigraphic implications," Journal of African Earth Sciences, vol. 42, no. 1-5, pp. 119-133, 2005.

[27] R. Han, H. Zou, W. U. Peng, W. Fang, Kunming, and Beijing, "Coupling Tectonic-Fluid Metallogenic Model of the Sandstone-Type Copper Deposit in the Chuxiong Basin, China," Acta Geologica Sinica, vol. 84, pp. 1438-1447, 2010.

[28] P. Muchez and M. Corbella, "Factors controlling the precipitation of copper and cobalt minerals in sediment-hosted ore deposits: Advances and restrictions," Journal of Geochemical Exploration, vol. 118, pp. 38-46, 2012.

[29] P. Muchez and M. Corbela, "Reactive transport modelling of ore mineral zoning and the paragenesis of copper sulfides in sediment-hosted stratiform ore deposits, the Katanga Copperbelt (DRC)," Geologica Belgica, vol. 19, no. 3-4, 2016.

[30] A. R. Cabral, G. Beaudoin, and B. E. Taylor, "The Transfiguration continental red-bed $\mathrm{Cu}-\mathrm{Pb}-\mathrm{Zn}$-Ag deposit, Quebec Appalachians, Canada," Mineralium Deposita, vol. 44, no. 3, pp. 285-301, 2009.

[31] E. M. Ripley, M. W. Lambert, and P. Berendsen, "Mineralogy and paragenesis of red-bed copper mineralization in the lower Permian of South Central Kansas," Economic Geology, vol. 75, no. 5, pp. 722-729, 1980.

[32] J. G. Price, J. N. Rubin, and S. W. Tweedy, "Geochemistry of the Vigas red-bed copper deposit, Chihuahua, Mexico," Economic Geology, vol. 83, no. 8, pp. 1993-2001, 1988.

[33] X. Liu, H. Fan, H. U. Fangfang, K. Yang, and Z. Qiu, "Research Progresses on Sediment-hosted Stratiform Copper Deposit," Geological Review, vol. 61, pp. 45-63, 2015.

[34] Z. Cheng, "A preliminary investigation of genesis and orecontrolling factors for sandstone hosted copper deposit in China," Acta Geology Sinica, vol. 38, pp. 28-44, 1975.

[35] Z. Rui, "On the replacement zoning of certain sttata-bound copper deposit," Acta Geologica Sinica, vol. 4, pp. 337-349, 1979.

[36] R. D. Jin, "Preliminary discussion on ore genesis of Jurassic sandstone copper deposits in northern Guizhou," Guizhou Geology, vol. 4, pp. 237-242, 1990.

[37] M. Q. He, C. Y. Ran, and H. D. Liu, "Organic characteristics and relationships to matallgenesis in Dayao copper deposit," Natural Gas and Oil, vol. 12, pp. 195-206, 1991.

[38] H. S. Chen and R. C. Y, Isotope Geochemistry for copper deposits in Kangdian Axis, Geology Publishing House, Beijing, China, 1992.

[39] J. Ding, Y. Wang, Z. Wang, and J. Cai, "Occurrence and geological characteristics of slver in Dayao copper deposit, Yunnan," Journal of Guilin Institute of Technology, vol. 12, p. 51, 1992.

[40] Y. Xu and S. Zhang, "The mieralization zoning of copper deposits in sandstone and its qpplication to the prospecting," Geological exploration for non-ferrous metals, vol. 3, pp. 135-140, 1994. 
[41] Z. C. Liu, F. Y. Li, and K. H. Zhong, Tectonic Evolution and Mineralization in Yangzi Platform Margin, University of Electronic Science and Technology Press, Chengdu, China, 1996.

[42] Y. Cui, "Sulfur isotope geochemistry of sandstone(shale)-hosted copper deposits in southern China," Geology-Geochemistry, vol. 2, pp. 25-29, 1997.

[43] F. Li and W. N. Pu, Geology of Copper Deposits in Western Yunnan, Yunnan University Press, Kunming, China, 2000.

[44] Y. S. Guo, Geology of Sandstone Hosted Copper Deposit in Central Yunnan, Yunnan science and Technology Press, Kunming, China, 2008.

[45] C. H. Liu, Geology of sandstone hosted copper deposit, Metallurgical Industry Press, Beijing, China, 1977.

[46] X.-F. Zhao, M.-F. Zhou, M. W. Hitzman et al., "Late paleoproterozoic to early mesoproterozoic tangdan sedimentary rock-hosted strata-bound copper deposit, yunnan province, southwest china," Economic Geology, vol. 107, no. 2, pp. 357-375, 2012.

[47] G. Z. Tu, Geochemical of Strata Bound Ore Deposits in China, Science Press, Beijing, China, 1984.

[48] C. Y. Ran and W. H. Liu, Geochemistry of copper deposits and their Meachanism of storeyed texture in Kangdian Axis, Science Press, Beijing, 1993.

[49] C. Y. Ran and H. P. Zhuang, Geochemistry of the associated copper, saline and organic deposits in the Chuxiong basin, Yunnan, Science Press, Beijing, china, 1998.

[50] H. P. Zhuang, C. Y. Ran, M. Q. He, and J. L. Lu, "The evidence and mechanism of the reaction s between water and rock in the metallogenic process in sandstone copper deposits, central Yunnan," Journal of China University of Geosciences, vol. 21, pp. 327-331, 1996.

[51] W. X. Wang, Metallogenic Prediction And Optimization of the Target of Sandstone Copper Deposits in Chuxiong Region, Geology Publishing House, Beijing, China, 1997.

[52] G. X. Tan, Geochemistry and metallogenic dynamics of sandstone copper deposits, Earthquake Press, Beijing, China, 1998.

[53] B. J. Liu, Sedimentary diagenesis, Geology Publishing House, Beijing, China, 1980.

[54] C. L. Zhao and X. M. Zhu, Sedimentary diagenesis, Petroleum Industry Press, Beijing, China, 3rd edition, 2000.

[55] G. Chen, B. Xia, Z. Zhong, and G. Wang, "Characteristics and genetic significance of metal mineral zonation of sandstonehosted copper deposits in Chuxiong, centtal Yunnan," Geologygeochemistry, vol. 30, pp. 41-45, 2002.

[56] H. W. Gao, "Application of thermodynamics Eh-pH to the zoning model of Dayao copper deposit," Journal of Mineralogy \& Petrology, vol. 30, pp. 77-81, 2010.

[57] J. D. Liu, C. J. Zhang, and X. F. Liu, Metallogenic regularities and prospecting direction in southwest margin of Yangtze platform, Geology Publishing House, Beijing, China, 2004.

[58] G. D. Chen, S. L. Peng, and T. G. Dai, The tectonics and metallogeny of Yunnan copper-polymetallic deposits, Zhongnan University Press, Changsha, China, 2004.

[59] T. J. B. Holland and R. Powell, "An internally consistent thermodynamic data set for phases of petrological interest," Journal of Metamorphic Geology, vol. 16, no. 3, pp. 309-343, 1998.

[60] A. E. Boudreau, "PELE-a version of the MELTS software program for the PC platform," Computers \& Geosciences, vol. 25, no. 2, pp. 201-203, 1999.
[61] C. X. Lin, Z. H. Bai, and Z. R. Zhang, The Thermodynamic Manual Book of Minerals and Related compounds, Science Press, Beijing, China, 1985.

[62] H. Z. Wu, Study on fluid inclusion of sandstone copper deposit in Chuxionng basin, central Yunnan, Kunming University of Science and Technology, Kunming, China, 2011.

[63] Z. L. Wang and Y. P. Zhou, Physical Chemistry, Higher Education Press, Beijing, China, 2001.

[64] R. M. Garrels, Solutions, minerals, and equilibria, Harper \& Row, New York, NY, USA, 2nd edition, 1965.

[65] N. Takeno, Atlas of Eh-pH diagrams Intercomparison of thermodynamic databases, vol. 223, 2005.

[66] M. H. Reed and J. Palandri, "Sulfide mineral precipitation from hydrothermal fluids," Reviews in Mineralogy and Geochemistry, vol. 61, pp. 609-631, 2006.

[67] R. Powell and T. J. B. Holland, "An internally consistent thermodynamic dataset with uncertainties and correlations: 2 . Data and results," Journal of Metamorphic Geology, vol. 3, no. 4, pp. 343-370, 1985.

[68] R. Powell and T. J. B. Holland, "An internally consistent dataset with uncertainties and correlations: 3. Applications to geobarometry, worked examples and a computer program," Journal of Metamorphic Geology, vol. 6, no. 2, pp. 173-204, 1988.

[69] L. S. Zhao and B. R. Zhang, Geochemistry, Geology Publishing House, Beijing, China, 1988.

[70] D. X. Qin, Q. Meng, and M. C. Yang, "The SedimentaryReformation origin of the Haojiahe copper deposit, Mouding county, Yunnan province," Mineral Deposits, vol. 2, pp. 97-108, 1993.

[71] S. Shen, Mineralization laws and prospect for main ore deposit in the Xichang-Central Yunnan area, Chongqing Publishing House, Chongqing, China, 1988.

[72] C. Y. Ran, Geochemistry of the Kangdian axis copper deposits and mechanism of storeyed texture of copper deposits, Science Press, Beijing, China, 1993.

[73] H. S. Chen and C. Y. Ran, Isotopic geochemistry of the Kangdian axis copper deposits, Geological Publishing House, Beijing, China, 1992.

[74] G. W. Chen, Y. Z. Wu, B. Xia, H. Wang, Z. H. Zhong, and G. Q. Wang, "Isotopic characteristics and genesis of ssandstonetype copper deposits in the Chuxiong Basin, Yunnan province," Geotectonic et Metallogenia, vol. 26, pp. 279-284, 2002.

[75] Y. Y. Hu, The geological characteristics and deposit genesis of sandstone copper deposit in Guihua Dacun of Chuxiong basin, Kunming University of Science and Technoloy, Beijing, China, 2016.

[76] D. W. Haynes and M. S. Bloom, "Stratiform copper deposits hosted by low-energy sediments: III. Aspects of metal transport." Economic Geology, vol. 82, no. 3, pp. 635-648, 1987.

[77] S. Speczik, "The Kupferschiefer mineralization of Central Europe: New aspects and major areas of future research," Ore Geology Reviews, vol. 9, no. 5, pp. 411-426, 1995.

[78] Y. Sun, W. Püttmann, and S. Speczik, "Differences in the depositional environment of basal Zechstein in southwest Poland: implication for base metal mineralization," Organic Geochemistry, vol. 23, no. 9, pp. 819-835, 1995.

[79] E. S. Ho and J. L. Mauk, "Relationship between organic matter and copper mineralization in the Proterozoic Nonesuch Formation, northern Michigan," Ore Geology Reviews, vol. 11, no. 1-3, pp. 71-88, 1996. 
[80] Y.-Z. Sun and W. Püttmann, “The role of organic matter during copper enrichment in Kupferschiefer from the Sangerhausen basin, Germany," Organic Geochemistry, vol. 31, no. 11, pp. 11431161, 2000.

[81] R. R. McGowan, S. Roberts, R. P. Foster, A. J. Boyce, and D. Coller, "Origin of the copper-cobalt deposits of the Zambian Copperbelt: an epigenetic view from Nchanga," Geology, vol. 31, no. 6, pp. 497-500, 2003.

[82] I. Subías, I. Fanlo, E. Mateo, and J. García-Veigas, "A model for the diagenetic formation of sandstone-hosted copper deposits in Tertiary sedimentary rocks, Aragón (NE Spain): S/C ratios and sulphur isotope systematics," Ore Geology Reviews, vol. 23, no. 1-2, pp. 55-70, 2003.

[83] S. J. Sutton and J. B. Maynard, "A fluid mixing model for copper mineralization at Konkola North, Zambian Copperbelt," Journal of African Earth Sciences, vol. 42, no. 1-5, pp. 95-118, 2005.

[84] R. R. McGowan, S. Roberts, and A. J. Boyce, "Origin of the Nchanga copper-cobalt deposits of the Zambian Copperbelt," Mineralium Deposita, vol. 40, no. 6-7, pp. 617-638, 2005.

[85] H. A. El Desouky, P. Muchez, and J. Cailteux, "Two Cu-Co sulfide phases and contrasting fluid systems in the Katanga Copperbelt, Democratic Republic of Congo," Ore Geology Reviews, vol. 36, no. 4, pp. 315-332, 2009.

[86] D. Schmandt, D. Broughton, M. W. Hitzman, P. PlinkBjorklund, D. Edwards, and J. Humphrey, "The Kamoa copper deposit, democratic republic of Congo: Stratigraphy, diagenetic and hydrothermal alteration, and mineralization," Economic Geology, vol. 108, no. 6, pp. 1301-1324, 2013.

[87] Ran Chongying, Zhang Zhijun, and Zhuang Hanping, "Geochemistry of the associated copper, saline and organic deposits in the Chuxiong Basin, Yunnan, China," Journal of the Chengdu Institute of Technology, vol. 25, no. 2, pp. 241-245, 1998.

[88] Z. Hanping, R. Chongying, H. Mingqin, and L. Jialan, "Interactions of Copper, Evaporite, and Organic Matter and Genesis of Sandstone-Hosted Copper Deposits in the Chuxiong Basin, Yunnan Province," Acta Geologica Sinica, vol. 9, no. 4, pp. 407419, 1996.

[89] C. Y. Ran, Formation Mechanism of Stratabound Copper Deposits in Kandian Axis, Geological Publishing House, Beijing, China, 1989.

[90] W. H. Yan and Y. M. Liu, "Geochemmistry of Mesozoic stratabound copper deposits in Central Yunnan, China," Science in China(Series B), vol. 8, pp. 833-841, 1983.

[91] A. Bechtel, Y. Sun, W. Püttmann, S. Hoernes, and J. Hoefs, "Isotopic evidence for multi-stage base metal enrichment in the Kupferschiefer from the Sangerhausen Basin, Germany," Chemical Geology, vol. 176, no. 1-4, pp. 31-49, 2001.

[92] H. G. Machel, H. R. Krouse, and R. Sassen, "Products and distinguishing criteria of bacterial and thermochemical sulfate reduction," Applied Geochemistry, vol. 10, no. 4, pp. 373-389, 1995. 

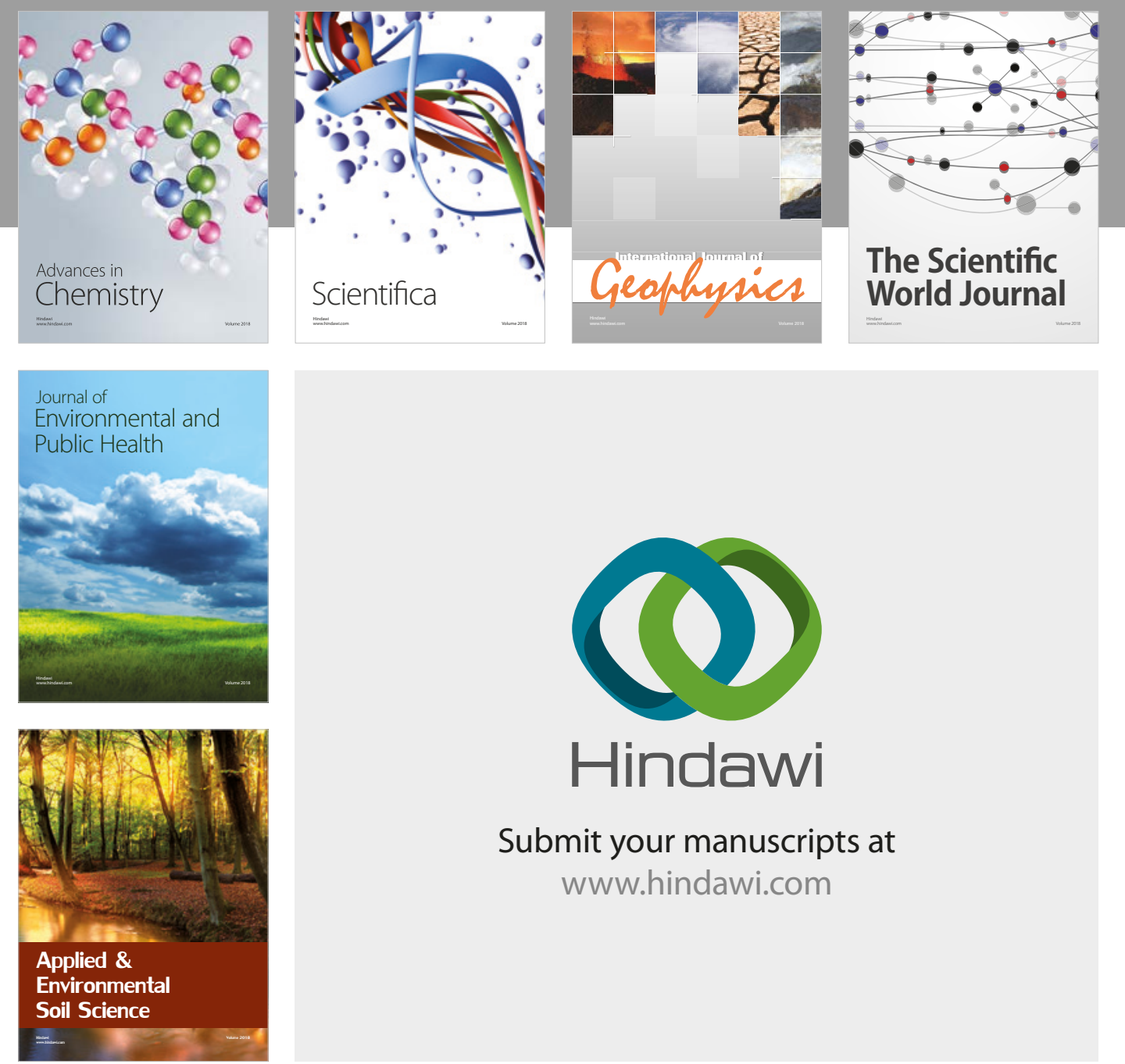

The Scientific

\section{World Journal}
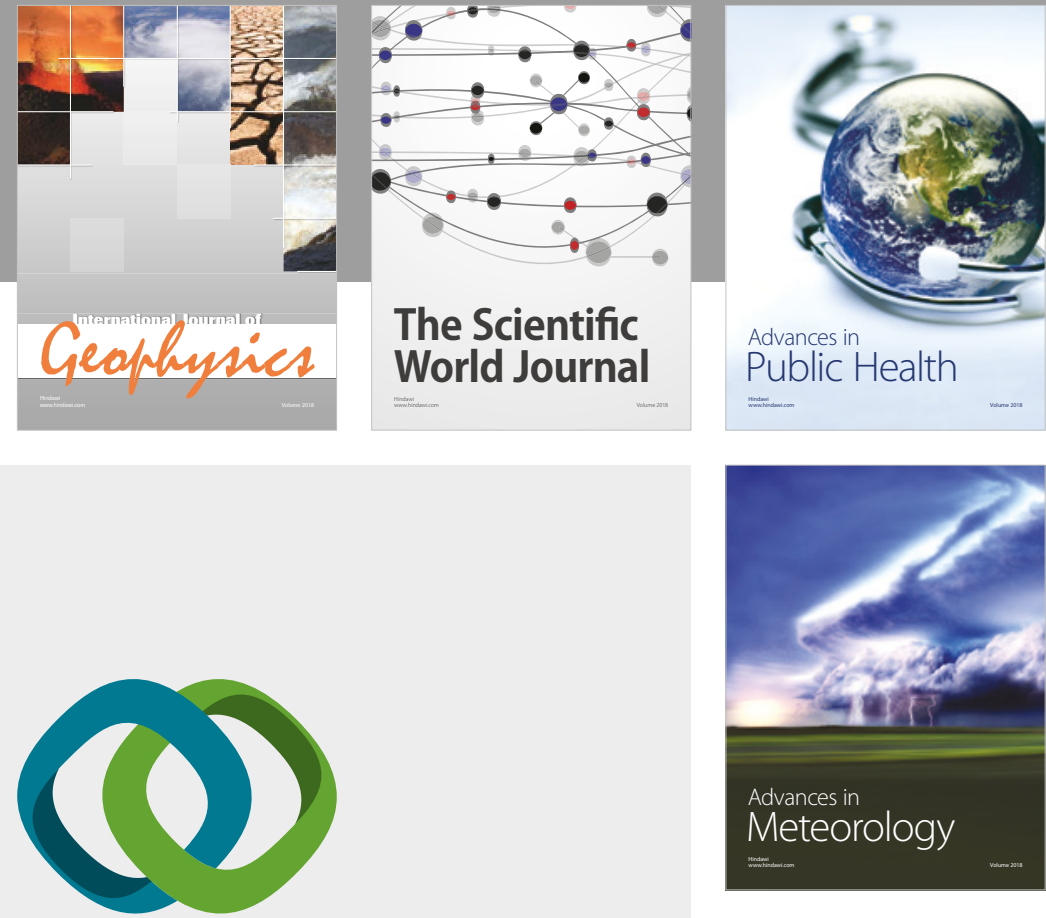

Advan

Public Health

\section{Hindawi}

Submit your manuscripts at

www.hindawi.com
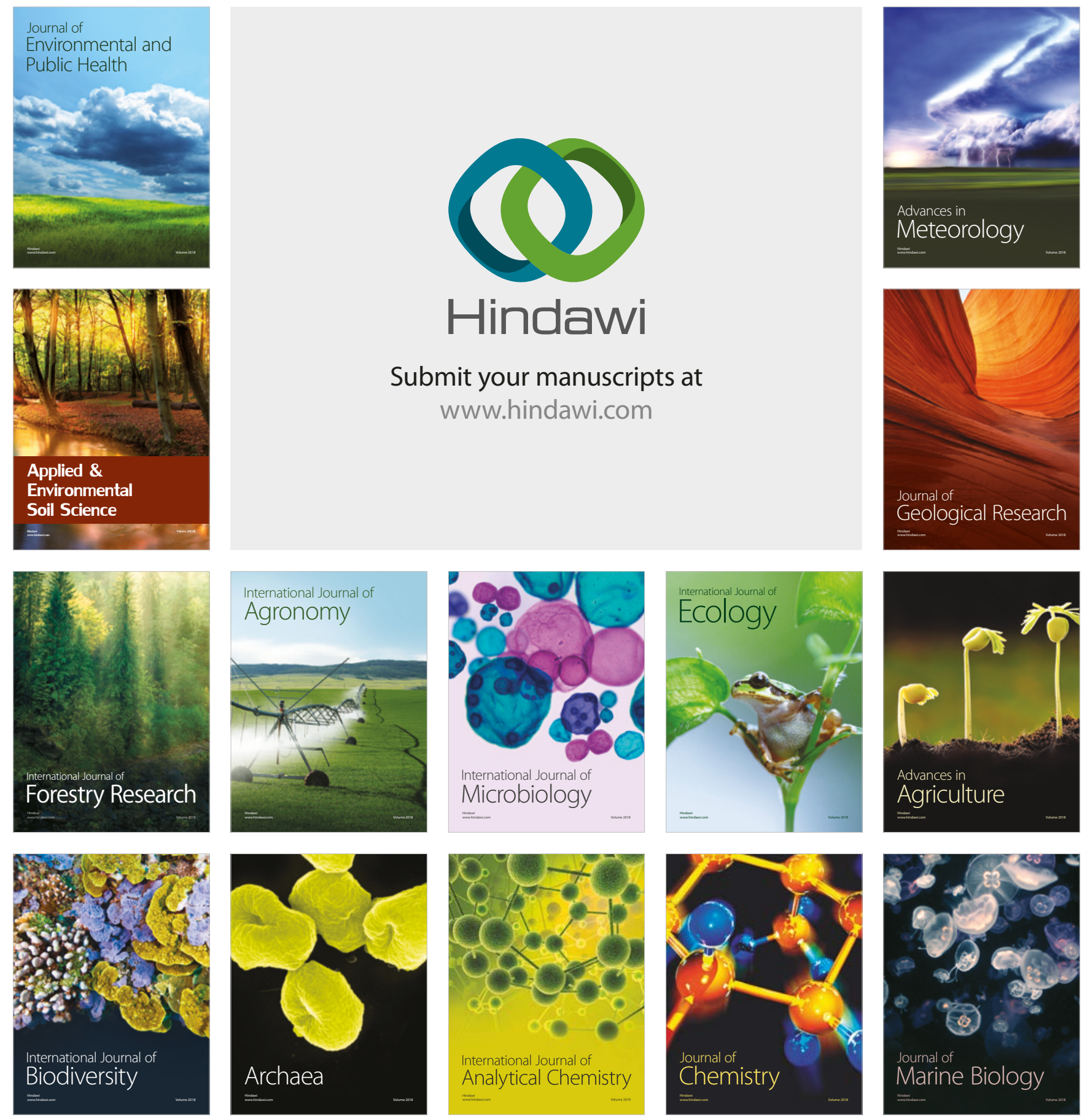